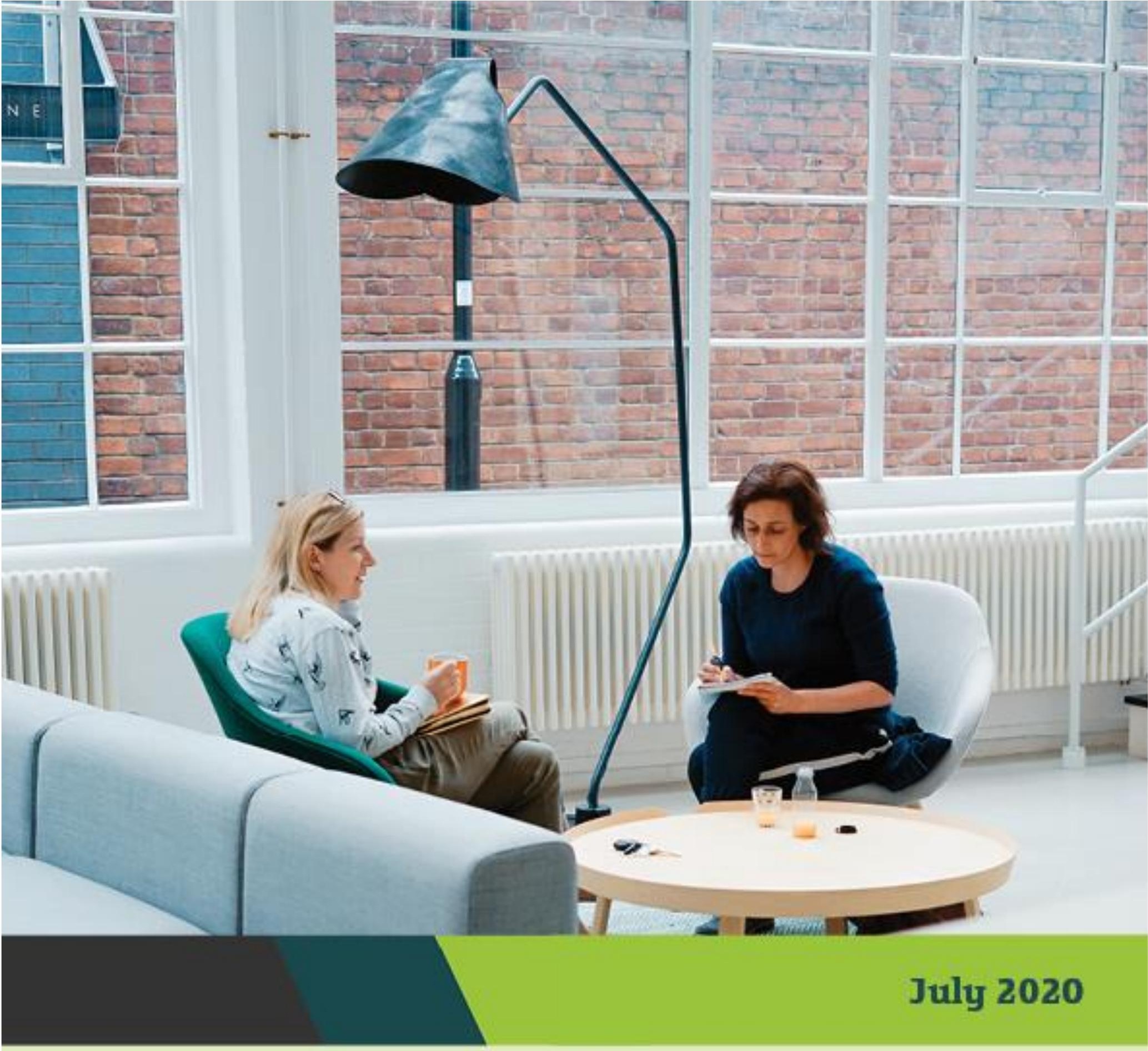




\section{Talent Match Evaluation: Comparative Report}

Authors

Chris Damm

Anne Green

Peter Wells

For further details contact: Professor Peter Wells (Evaluation Director) at p.wells@shu.ac.uk / 01142253073

July 2020

DOI: 10.7190/cresr.2020.8135640588 


\section{Acknowledgements}

We are extremely grateful to all those who have helped in the course of the evaluation. We are particularly grateful to the staff, young people and board members of the 21 Talent Match partnerships who have given their time freely to support the evaluation. A particular mention should be made of partnership leads and those involved in setting up the Common Data Framework (CDF). We trust that in time the considerable benefits of the CDF will be seen in terms of contributing to a robust evidence base on which to design future policies and programmes.

A wide range of staff and committee members at The National Lottery Community Fund have helped, supported and advised upon the evaluation. Their time has been invaluable. We are particularly grateful to Jolanta Astle, Sarah Cheshire, James Godsal, Scott Hignett, Scott Hyland and Roger Winhall. We are also grateful to Matt Poole, Linzi Cooke and Scott Greenhalgh who provided invaluable assistance at the start of the Talent Match Evaluation.

Lastly, we would like to thank the evaluation team at Sheffield Hallam University, the University of Birmingham, the University of Warwick and Cambridge Economic Associates: Duncan Adam, Gaby Atfield, Dr Sally-Anne Barnes, Nadia Bashir, Dr Richard Crisp, Dr Chris Damm, Dr Maria de Hoyos, Dr Will Eadson, Professor Del Roy Fletcher, Dr Tony Gore, Professor Anne Green, David Leather, Elizabeth Sanderson, Emma Smith, Louise South, Professor Pete Tyler, Sarah Ward and lan Wilson. We would also like to thank our former colleague Ryan Powell who supported the original evaluation design and engagement with all the partnerships.

Peter Wells (Evaluation Director) and Sarah Pearson (Evaluation Project Manager) 


\section{Contents}

\section{Summary}

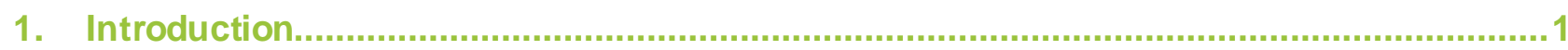

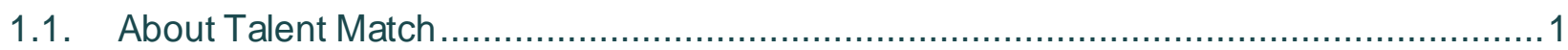

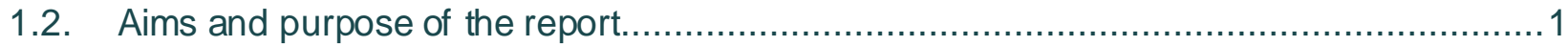

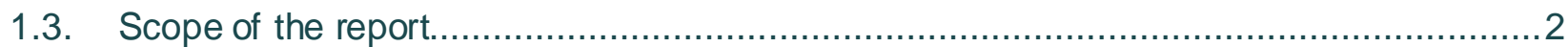

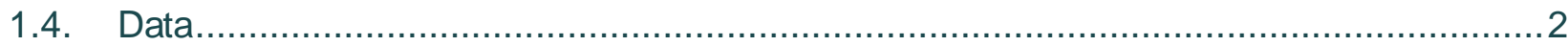

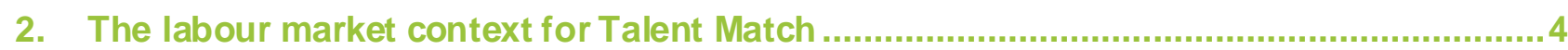

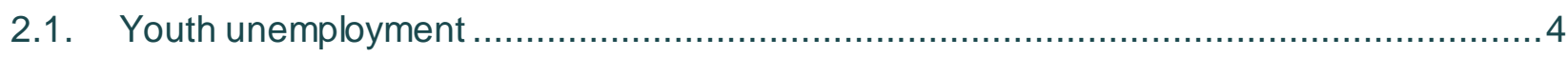

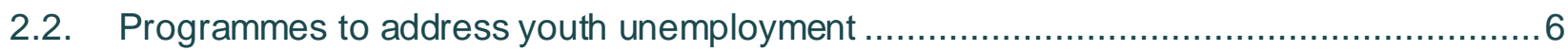

2.3. Changing youth transitions and the labour market case for Talent Match .........................9

2.4. Conclusion: comparators for Talent Match ..........................................................10

3. Comparative models: a strategic perspective .......................................................... 12

3.1. Models and paradigms underlying youth employability programmes .........................12

3.2. The strategic objectives, rationale, ethos and governance of Talent Match ....................12

3.3. Conclusion: strategic assessment of Talent Match in a comparative perspective ...........14

4. Programme design at the direct contract level........................................................ 16

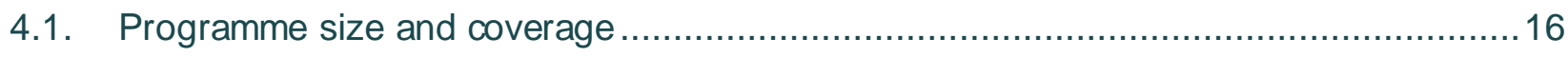

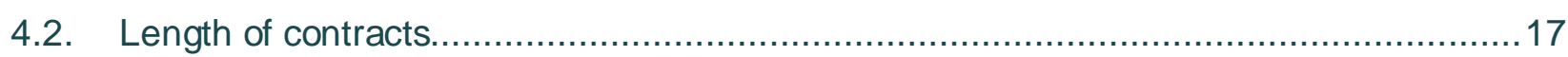

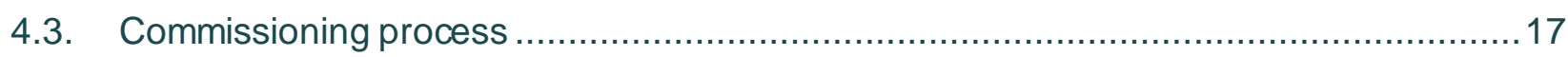

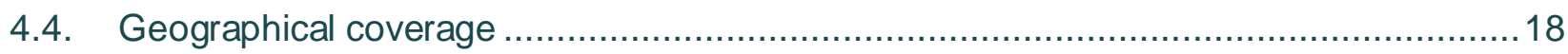

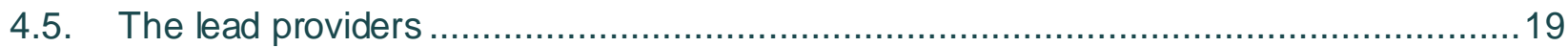

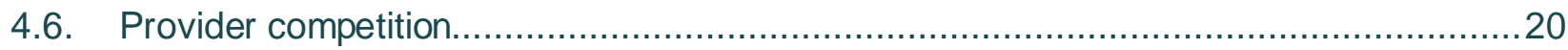

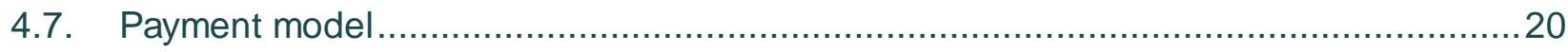

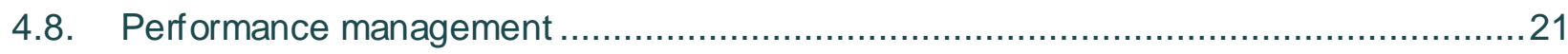

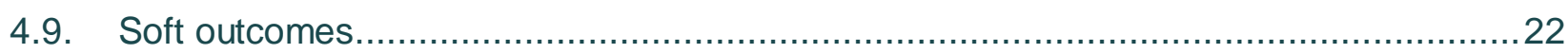

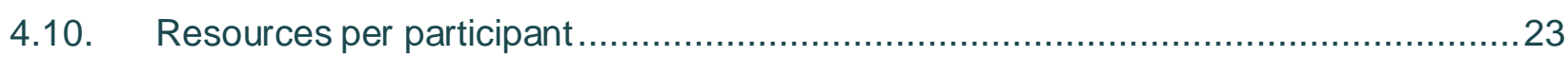

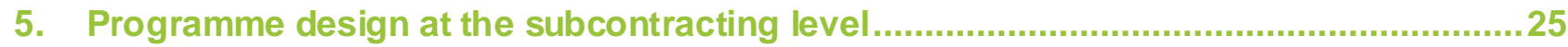

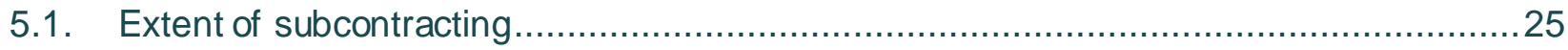

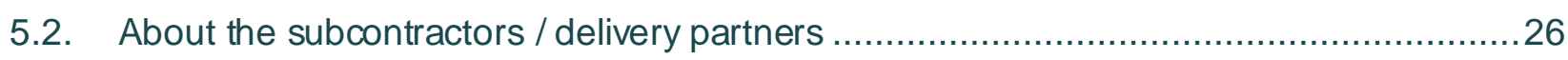

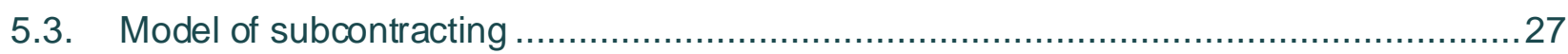




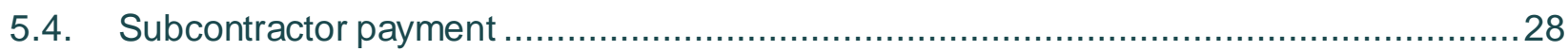

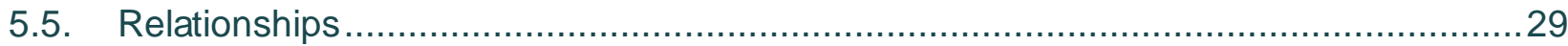

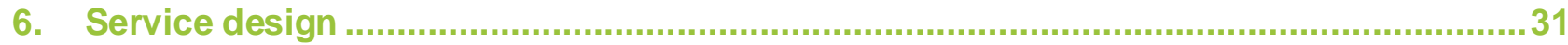

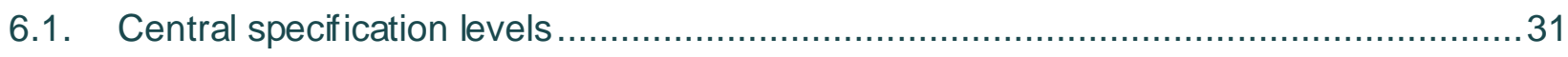

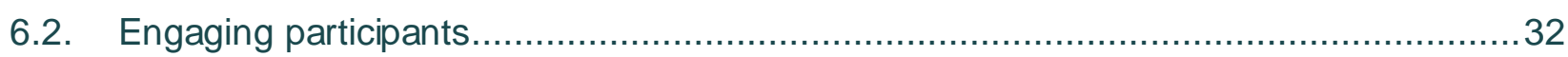

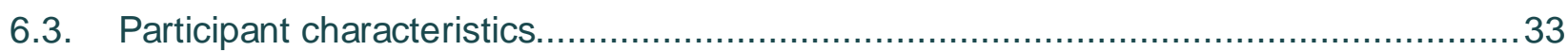

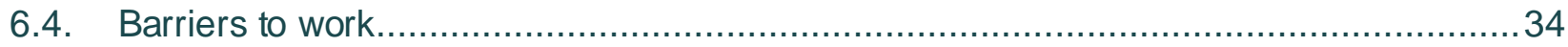

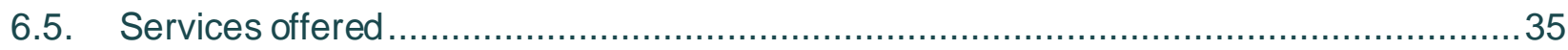

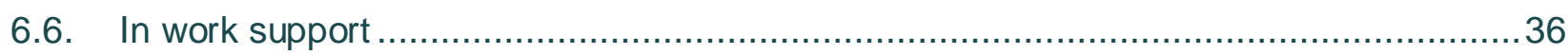

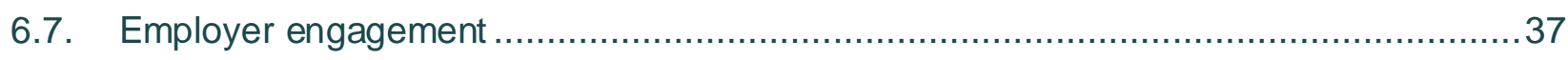

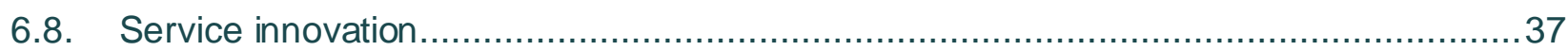

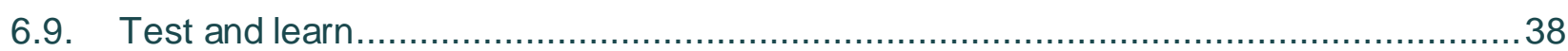

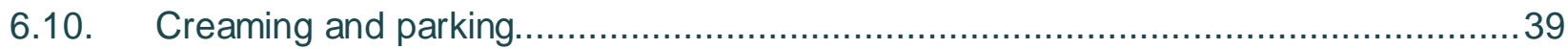

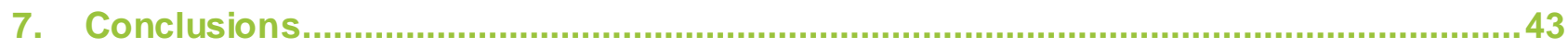

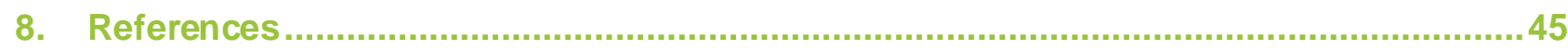

Annex 1: Summary table................................................................................... 48 


\section{Summary}

\section{Introduction}

This report explores the design of Talent Match and locates the programme in the context of wider employment policy and programmes. In doing so it compares the design of Talent Match to the Work Programme, the most prominent, publicly funded and contemporary source of unemployment services to young people.

The report aims to:

- $\quad$ provide the labour market context for Talent Match;

- explore the paradigms that underpin Talent Match;

- compare the commissioning process for Talent Match and the Work Programme at the direct contracting level;

- compare subcontracting arrangements;

- compare the design and delivery arrangements of the service provision on each programme.

\section{Labour market and policy context}

Young people were disproportionately affected by the 2008 recession and those facing the most disadvantage have been most impacted by ongoing labour market changes. In response, The National Lottery Community Fund (hereafter the Fund) established Talent Match in 2012 to support young people who were furthest from the labour market through personalised, nonstandardised provision. Talent Match was designed and conceived during a period of peak unemployment for young people, although rates fell over the course of the programme's operation. It was also initially designed to address concern over young people were not in receipt of benefits, and 'hidden' from the official employment and skills system.

Over the last forty years a range of mainstream national programmes have sought to support young people into work. At the time that Talent Match was implemented, the Work Programme was the mainstream publicly funded programme (covering all working age groups).

\section{Comparative models: a strategic perspective}

Employment programmes often fall into one of two different models. Work First programmes prioritise entry to work at the earliest opportunity. The main emphasis of this approach is on job search assistance, short-term work preparation activity, targeted short-term work experience and support to help with barriers to work such as transport, clothes and tools for jobs. Human Capital approaches, in contrast, seek to increase skills and qualifications to reduce the disadvantages that individuals face before assisting them to find work. The Work Programme was predominantly a Work First programme. While Talent Match contained many 
Work First elements, it also incorporated some elements of a more human capital-based approach.

Key principles of Talent Match included:

- partnership and coordination at the local level;

- localised solutions;

- youth involvement and co-design;

- voluntary sector leadership;

- $\quad$ a test and learn approach to delivery;

- voluntary participation.

\section{Programme design at the direct contract level}

The Work Programme was a much larger programme than Talent Match, geographically and in terms of total spending, although Talent Match was still large for a voluntary sector led, grant funded programme. In terms of the resources per participant, however, resources were much tighter on the Work Programme, partly due to its payment by results funding model. Whereas the Work Programme was a national, universal programme, Talent Match was much more geographically targeted, although this relaxed over the course of the programme.

There was considerable diversity in the size and background of Talent Match lead partners and Work Programme 'prime providers' (or 'primes'). Reflecting the size of the contracts, primes were generally larger and were mainly from the private sector. Talent Match lead partners were all from the voluntary sector, though some were social enterprises rather than charities.

While the Work Programme incorporated several elements of market competition, Talent Match was more partnership based. The Work Programme was also more tightly performance managed, with minimum performance targets for some groups of participants. In terms of monitoring, both programmes focussed primarily on job outcomes, though Talent Match recorded more information on soft outcomes and the Work Programme had a stronger emphasis on sustained employment.

\section{Programme design at the subcontracting level}

Both programmes operated subcontracting models and the degree of subcontracting varied between different contracts or partnerships. There was also great variation on both programmes in the size and background of subcontractors. The main point of distinction was that whilst on the Work Programme, there were similar proportions of voluntary and private sector end-to-end subcontractors, on Talent Match, most delivery partners were from the voluntary sector.

Work Programme prime providers followed a range of different approaches to subcontracting, while Talent Match was more consistently based around partnerships. A variety of payment models for subcontracting were seen on both programmes, but payment by results was more likely to be passed onto subcontractors on the Work Programme. Relationships between direct contractors and subcontractors varied, but generally there was a much higher scope for performance management on the Work Programme than on Talent Match. Overall, relations between direct contractors and subcontractors on both programmes appear to have been largely positive based on provider survey responses. 


\section{Service design}

Eligibility for the Work Programme was based on the length of time spent on certain benefits. Talent Match initially focussed on young people not in work, training, education or on benefits, but as the programme progressed, being out of work became the main eligibility criteria.

Whereas Work Programme participation was compulsory and relied on referrals from the Job Centre Plus, Talent Match partners had to recruit young people. They did so primarily via peerto-peer methods or referrals from other organisations, including the Job Centre Plus in some cases. Participants on both programmes were more likely to be male, white, non-disabled and to live in deprived areas. Although comparisons are difficult, it appears that Talent Match participants were more likely to have faced significant adverse life events.

Both programmes offered a core of work-first based interventions. For at least some participants, however, Talent Match also offered a second tier of more intensive interventions. Both programmes also offered in-work support and engaged with employers to at least some degree. Both programmes exhibited very high levels of flexibility for providers to design their own services, though Work Programme providers were more beholden to pledges made at the bidding stage. Talent Match partnerships were more likely to exhibit examples of innovation and adapted as part of a 'test and learn' approach. The role of young people in design and delivery stands out as perhaps the main innovation of Talent Match. Provision on the Work Programme sought to balance the cost of provision against the likelihood of outcome payments under payment by results. Talent Match providers did not experience this financial pressure and were freer to be flexible in the levels support offered to any young person.

\section{Conclusions}

Whereas the Work Programme embodied the principles of the market and public sector contracting, notably payment by results, Talent Match arguably adopted a more network, partnership-based approach. There were clear differences in terms of the ethos, contract design and services. Perhaps less obviously, however, there were also several similarities in terms of each programme's core offering. Neither can be caricatured as the embodiment of either grant based, voluntary sector provision or of public sector outsourcing to monolithic private sector contractors. This report therefore highlights that whilst in some ways Talent Match mirrored existing provision, in others it was a genuinely innovative and distinctive form of provision for young unemployed people.

\section{Lessons for policy}

Programme design is vitally important to the eventual character of a programme. If certain programme characteristics are desired, such as innovation over the course of delivery, targeting the hardest to help, or balancing job outcomes against 'softer' outcomes, then these need to be explicitly reflected in the programme design.

Although already distinctive, Talent Match could, if desired, have been differentiated even further from the Work Programme in a number of ways. For example, it could have focussed more on job subsidisation, weakened the focus on job outcomes, or scaled back work-first provision and increased the amount of intensive intervention. These would not necessarily have led to a 'better' programme, but it is important to highlight that these are important design decisions for this and future programmes.

Finally, it should be borne in mind that many of the design features discussed in this report have cost implications. Talent Match partnerships were able to spend a much higher average amount per participant than the Work Programme and it is this investment, above all else, which allowed innovation in its delivery and design. 


\section{Introduction}

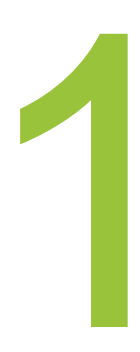

\subsection{About Talent Match}

The National Lottery Community Fund (the Fund) (then the Big Lottery Fund) invested $£ 108$ million in Talent Match, a programme designed to address unemployment amongst 18-24-year olds. It was delivered using National Lottery funding between 2014 and 2018 through voluntary sector led partnerships in 21 Local Enterprise Partnership areas in England. The programme sought to support young people who are furthest from the labour market through personalised provision which addressed their needs and aspirations.

\subsection{Aims and purpose of the report}

This report situates Talent Match in the wider context of youth unemployment and related service provision in England. It also explores in depth the way Talent Match was designed, compared against the main form of public sector provision over the same period, the Work Programme. The purpose of this comparison is to highlight the ways in which Talent Match succeeded in providing a relatively distinctive offering to young unemployed people. Talent Match aimed to build upon, not replicate, existing provision. It sought to offer a different type of employment support to the compulsory, work-first focussed provision offered under the Work Programme. This report therefore helps to assess whether Talent Match lived up to its foundational principles of being partnership based, voluntary sector led, locally designed, voluntary (non-compulsory), involving young people in its design and delivery, and based on a test and learn approach.

By exploring in-depth, therefore, where the programmes contrast in their design and operation, it is intended that the design of both becomes clearer than in isolation. Although outcomes and value for money are outside the scope of this report (see instead Wilson et al. 2019), it is clearly necessary to under stand the context and design features of Talent Match in order to judge its performance on its own terms, in accordance with its underlying principles and ethos.

The report also acts as a published, comprehensiveand detailed account of the design of Talent Match for future reference, which will prove useful for future funders or providers aiming to establish new youth unemployment programmes. It highlights the myriad design choices which form the design of an employment programme. Many of these choices lie on a spectrum, for example between private sector or voluntary sector provision, work-first or human capital-based approaches, partnership or hierarchical based contracting. Talent Match and the Work Programme lie at different points on these various spectra and comparing their design should help those involved in the design of future service provision to understand the choices available to them. In particular, those seeking to design a distinctive 'voluntary sector' programme may 
wish to use the information contained as either a model, or even as a benchmark against which to design an even greater contrast to mainstream programmes such as the Work Programme.

\subsection{Scope of the report}

This report explores the design of Talent Match in-depth and locates the programme in the context of wider employment policy and programmes. A wide-ranging literature review was undertaken as part of this research to identify the many programme features and decisions which, taken together, make up the design of an employment service. The literature suggested four broad aspects for comparison: values and ethos, commissioning design (at both the 'prime' and subcontracting levels), service de sign, and outcomes. This report focuses primarily on the first three of these aspects.

Issues related to measuring outcomes, cost-benefits and value for money can be complex (Greenberg et al., 2011). Headline comparisons of outcomes between Talent Match and other employment services are challenging and potentially invidious due to the very large number of confounding differences relating to their design and context. In addition, there are often differences in the way that outcomes are measured. The outcomes, additionality and impact achieved by Talent Match are explored in a companion report which tackles these issues explicitly and in-depth (Wilson et al., 2019).

Chapter 2 provides the labour market context for Talent Match, including trends in youth unemployment and the programmes designed to tackle it. Chapter 3 explores the paradigms that underlie Talent Match, relating to its rationale, ethos and objectives. The remaining chapters are more technical and hone-in on the Work Programme as a comparative case study for Talent Match. Chapter 4 examines the design of the commissioning process for both programmes at the direct contracting level (prime providers and partnership leads). Chapter 5 explores subcontracting arrangements (end-to-end subcontractors and delivery partners). Finally, chapter 6 explores the design and delivery arrangements of the service provision on each programme.

The Work Programme was the dominant form of public sector provision over the lifespan of Talent Match and primarily operated with different underlying assumptions and principles. As such, it provides a natural point of comparison. Considerable evidence is also available on the design and operation of the Work Programme via its official evaluation. Exploring how the two programmes differ, or are alike, in their aims, organisation and context, is intended to make explicit the many implicit and explicit aspects of their design. This in turn should allow a more informed consideration of whether each programme has been successful on its own terms and within the constraints and opportunities it faced.

\subsection{Data}

This report draws on a range of data sources from the Talent Match evaluation, which are described in-depth in a companion report (CRESR, 2019). In particular, the report uses longitudinal surveys of Talent Match participants, partnership leads and delivery partners.

For data on the Work Programme, this report draws largely on the official evaluation reports published by the Department of Work and Pensions (DWP) (Newton et al., 2012; Lane et al., 2013; Meager et al., 2014; Foster et al., 2014). In some cases, further analysis or evidence is also drawn from the wider literature and policy debate on the Work Programme. 
As part of the official evaluation (Foster et al., 2014), Work Programme subcontractors were surveyed online in 2012, 2013 and 2014. At each of these waves of research, qualitative research was also undertaken with prime providers, subcontractors, DWP and JCP staff. Work Programme participants were also surveyed by phone to explore their experiences in 2012 and 2014. Further details of the methodologies used can be found in the relevant evaluation reports. 


\section{The labour market context for Talent Match}

This chapter sets out the labour market rationale for the Talent Match programme given trends in youth unemployment. Looking beyond official administrative and survey statistics it examines growing concerns about young people who are not counted in the statistics and so who are 'hidden' from the official public gaze. It gives a brief historical overview of programmes to address unemployment, with a particular focus on more recent years. It outlines key features of labour market change and changing youth transitions. This sets the context for the labour market case for Talent Match. Of course, Talent Match was not the only programme focusing on young people at this time; rather it operated alongside mandatory national active labour market programmes and a range of voluntary initiatives operating at the local level.

\subsection{Youth unemployment}

\section{Trends in youth unemployment}

Figure 2.1 shows trends in the ILO unemployment rate ${ }^{1}$ from 1971 to 2018 for those aged 16-64 years and from 1992 to 2018 for young people aged 18-24 years. Over the period from 1992 when data for young people are available it is clear that the ILO unemployment rate for 18-24 year olds remained considerably higher than for those aged 16-64 years. The increase in the ILO unemployment rate in the 'Great Recession' was much more marked for young people than for all adults. The ILO unemployment rate for 18-24 year olds rose from slightly over 10 per cent between 2000 and 2004 to 12.2 per cent in 2006 and 2007 and 17.3 per cent in 2009 , peaking at 19.3 per cent in 2012 before declining to 13.2 per cent in 2015 and 10.2 per cent in 2018 . The rise in youth unemployment at the time Talent Match was conceived and designed also spawned the introduction of other initiatives (nationally and locally) seeking to help young people into employment. By the time that Talent Match (and other local initiatives) was implemented, youth unemployment was relatively high but declining. This had the potential to lead to confusion and tensions when different organisations were seeking to help the same beneficiaries.

Figure 2.2 shows trends in the Jobseeker's Allowance (JSA) claimant count for 18-24 year olds in the UK over the period from 1996 to 2017 distinguishing between those claiming for more than and less than 6 months. The number of JSA claimants in this age group peaked in 2009 and 2011 at around 460 thousand. Hence the claimant count declined markedly during the period when Talent Match was implemented.

\footnotetext{
${ }^{1}$ The ILO unemployment rate covers those who are out of work and want a job, have actively sought work in the last four weeks and are available to start work in the next two weeks; plus those who are out of work, have found a job and are waiting to start in the next two weeks.
} 
Figure 2.1: ILO unemployment rate in the UK, 1971-2018

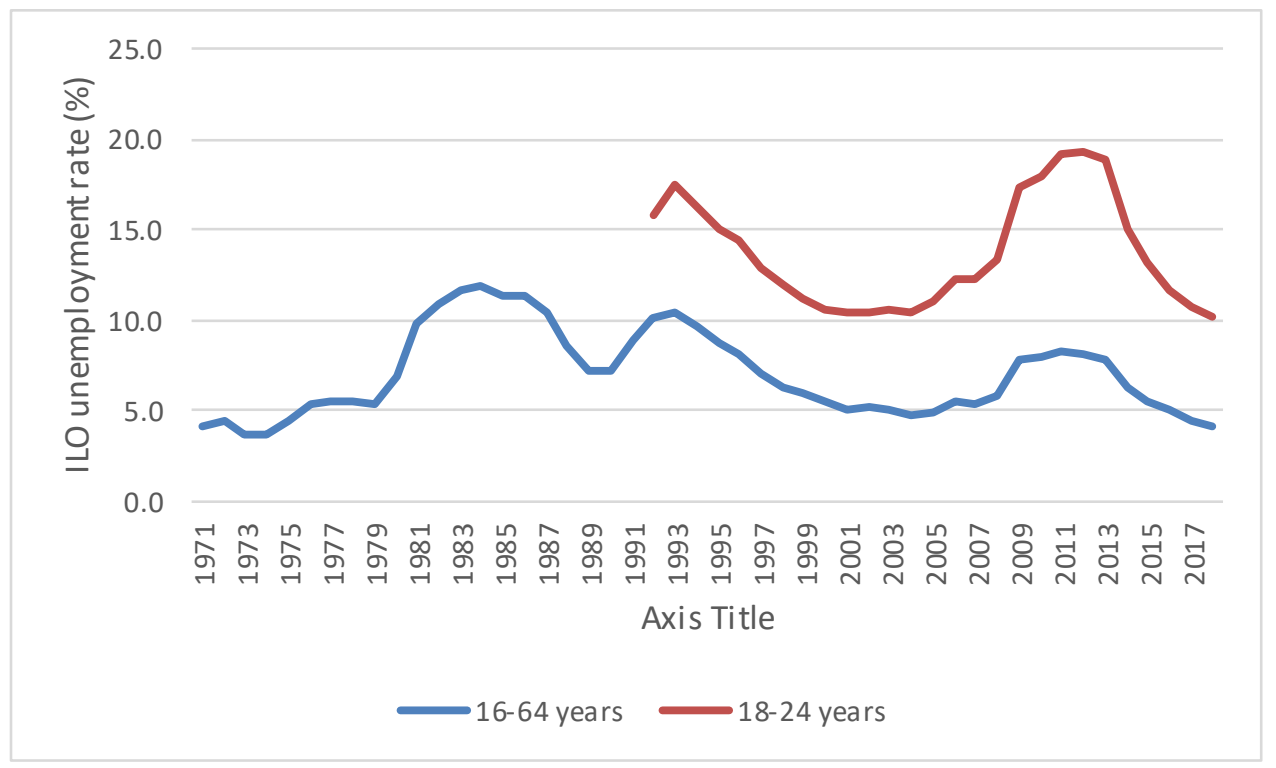

Source: Labour Force Survey (via Nomis)

Figure 2.2: JSA claims in the UK, 1996-2017

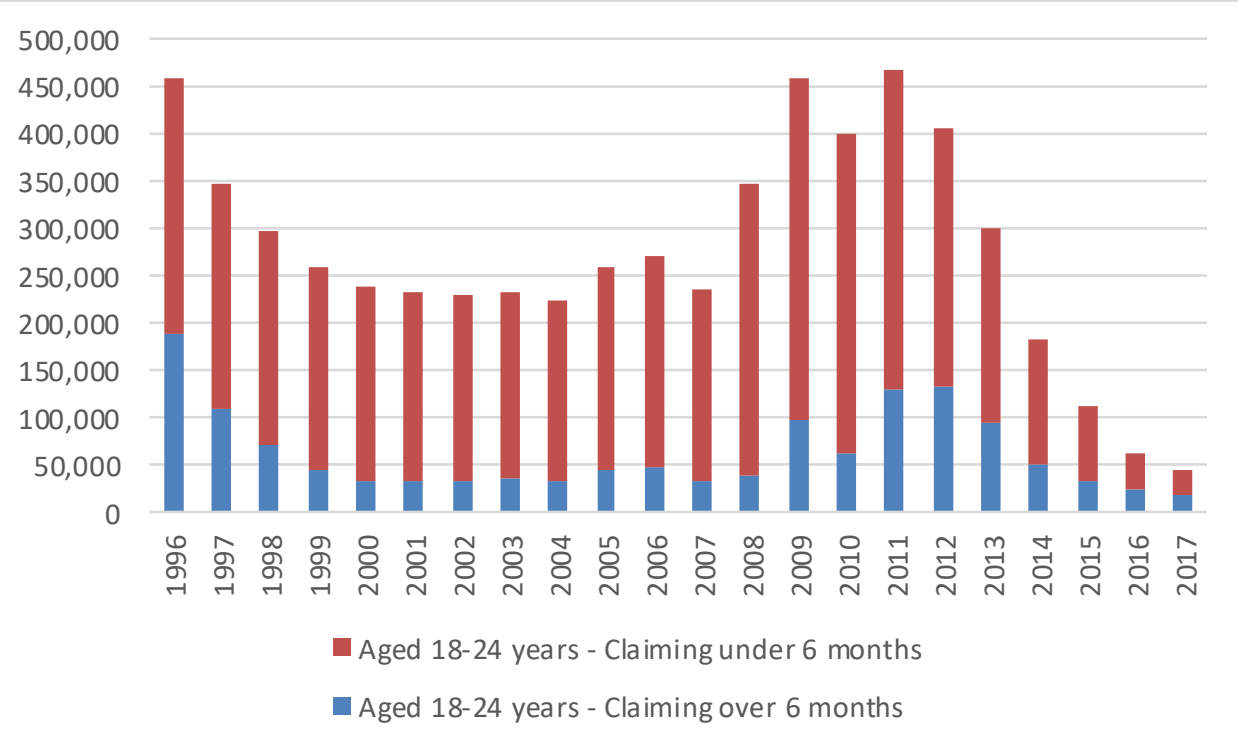

Source: JSA claims (via Nomis)

These trends at national level mask spatial variations in unemployment and the claimant count at a local level. At sub-national level sampling variation in the Labour Force Survey means that small changes in statistics reported for young people need to be interpreted with caution, while with regard to administrative statistics latterly the phased roll-out of Universal Credit (UC) has implications for the interpretation of claimant count data at local level. (JSA and UC are discussed in more detail subsequently.)

\section{Who is counted?}

The statistics presented above show a significant fall in youth unemployment over the medium-term. Talent Match was implemented during a period of considerable welfare reform. Concerns have been expressed that changes in the benefits system, including 
increasing use of mandatory requirements and conditionality, including the use of benefit sanctions, may have led young people who would otherwise claim benefits not to do so. In written evidence presented in September 2016 to the House of Commons Work and Pensions Committee's Enquiry on 'Employment Opportunities for Young People' (WPC, 2017) the Learning and Work Institute estimated that data show that: "the proportion of unemployed young people (not counting students) who are not claiming Jobseeker's Allowance and therefore are not receiving official help with job search is now 59.7 per cent and has risen by more than thirty percentage points since October 2012."

In their subsequent 2017 report the House of Commons Work and Pensions Committee (WPC, 2017) noted that they had received evidence that some young people perceive the benefits of using Jobcentre Plus as insufficient to justify the demands that the service places upon them and that some young people found attending Jobcentre Plus intimidating and stressful. Several witnesses emphasised that young people with greater barriers to work needed a more tailored, personalised approach. Some Talent Match beneficiaries expressed similar sentiments.

Overall, this suggests that there a sizeable proportion of young people who are out of work and 'hidden' from the official gaze of the benefits, employment and skills system. According to the Impetus-PEF Youth Jobs Index (2017), one in four 16-24 year olds spend some time Not in Education, Employment or Training (NEET), with over 800 thousand spending a year or more in NEET. This suggests that despite what conventional statistics suggest, a structural, as opposed to cyclical, youth unemployment problem remains. This group may include some who were able to subsist with other support (from their family for example) or who have secured income in the informal economy. However, for individuals outside the labour market for longer periods, there is well established evidence around the longer-term effects in terms of wage scarring, but also physical and mental health (ACEVO, 2015; McQuaid, 2015).

Research using the Longitudinal Education Outcomes (LEO) dataset (Gadsby, 2019) shows that disadvantaged young people are twice as likely to be NEET as their betteroff peers and that this gap has remained consistent over the period from 2010 to 2017. The gap is even larger in the North East and in Yorkshire \& the Humber and smaller in London - suggesting that local labour demand may play an important role in spatial variations in young people's experience. At a national level, half of the gap between disadvantaged young people and their better off peers can be explained by differences in qualification levels, suggesting that additional support needs - such as mental health support and housing advice - need to be addressed too, as education and training alone cannot bridge the gap.

\subsection{Programmes to address youth unemployment}

Over the last 40 years there has been a range of programmes and initiatives from successive Governments, of different political persuasions, aimed at addressing youth unemployment. Key features of the main programmes are outlined below, albeit it should be borne in mind that these are not the only interventions and benefit changes that impacted on young people over this period.

In 1978 the Youth Opportunities Programme (YOP) provided 12 months' work experience and training for school leavers aged 16-18 years. Replacing YOP the Youth Training Scheme (YTS), introduced in 1983, combined training and work experience for 16-17 year olds. In 1998 YTS effectively became the only way for the young unemployed to secure out-of-work income given the removal of young people aged under 18 years from Unemployment Benefit. YTS was rebranded as Youth Training in 1990. During the 1980s conditionality intensified as job seekers were required to attend Jobcentres more frequently and demonstrate they were actively 
looking for work, while lower benefit payments were introduced for claimants aged under 25 years without children. Job Seeker's Allowance (JSA), a new benefit merging Unemployment Benefit and Income Support, was introduced in 1996. There were benefit sanctions for failing to look for work, leaving jobs without due reason or for misconduct and refusing to attend courses or not complying with directions from the Jobcentre. Hence from the late 1970s to the mid-1990s the emphasis of youth employability programmes was on work experience and training, in the context of increases in conditionality.

In 1998 the New Labour Government introduced the New Deal for Young People (NDYP) for young people aged 18-24 years in receipt of JSA for six months. NDYP involved a 'Gateway' period of intensive job search followed by participation in one of four options: a subsidised job, a place on the Environment Task Force, a placement with a voluntary sector employer, or full-time education or training. Referral was mandatory and those eligible young people who failed to comply were subject to sanctions. NDYP was part of a broader suite of 'New Deal' programmes focusing on different labour market sub-groups, such as lone parents and disabled people.

In the face of rising youth unemployment in 2009 the Future Jobs Fund (FJF) was introduced for young people aged 18-24 years who had been in receipt of JSA for at least six months. The FJF created subsidised jobs in the public or third sector. In 2010 the FJF became part of the Young Person's Guarantee (YPG) which offered all 1824 year olds who had been in receipt of JSA for six months a job, training or work experience.

From 2011 the Work Programme was the mainstream employment programme for long-term unemployed. JSA claimants aged 18-24 were referred to the Work Programme after nine months unless they faced significant disadvantage. It was a mandatory programme offering a range of back-to-work support delivered by a range of organisations spanning the private and third sector. Utilising a 'black box' approach providers had flexibility to tailor support to meet individual and local area needs. Referrals to the Work Programme ended in March 2017 but it continued to support participants until early 2019.

The Work Programme was replaced by the smaller (in scale and scope) Work and Health Programme (WHP), providing specialist support for those who are likely to be able to find work within 12 months. In practice many young people previously supported by the Work Programme received support from the Jobcentre rather than the WHP.

In 2012 the Government launched the Youth Contract which was a package of schemes aimed at helping young people into sustained employment. It combined existing and new schemes and included an offer of work experience or a place on a sector-based work academy (involving a mixture of training, work experience and a job interview) for unemployed JSA claimants aged 18-24 years; extra Personal Adviser time at the Jobcentre and a careers interview in the first three months of a claim. For employers it included an Apprenticeship Grant for employers of 16-24 year olds and also wage incentives to engage unemployed young people. Although the Youth Contract was a national scheme some local areas - Leeds City Region, Liverpool and Newcastle - received central funding to devise their own localised Youth Contracts.

Over time more young people have been affected by Revised Lone Parent Obligations which have successively reduced the age of the youngestchild at which lone parents must actively seek work. This highlights how certain groups of young people - in this instance lone parents - are impacted not only by changes in youth employment programmes but also by changes in the benefits regime affecting other labour market sub-groups of which they might form part. 
From 2013 Universal Credit (UC) was rolled out in phases across the UK replacing six existing payments for working age people: Income Support, Income-Based JSA, Income-Related Employment Support Allowance, Housing Benefit, Child Tax Credit and Working Tax Credit). The standard allowances within UC are lower for the under 25s than for those aged 25 years and over. Under UC individual 'Claimant Commitments' increase job seeking expectations for most claimants and the default requirement is that claimants treat job-seeking as a full-time job. Importantly, UC claimants on low incomes were subject to conditionality for the first time to increase their earnings.

The introduction of the Youth Obligation (YO) in UC full service areas from 2017 placed an effective (mandatory) requirement on school leavers and young people claiming UC to either 'earn or learn'. In practice 18-21 years olds making a new claim received intensive work focused support from day one of their claim, including practising job applications and interviews together with job search. Each individual was assigned a work coach. If the claimant was still unemployed and claiming Universal Credit after six months they are expected to apply for an apprenticeship, traineeship, gain work-based skills or take up a work placement.

The programmes and benefit changes outlined above are largely national in nature and have involved UK Government funding. European funding has been a further source of funding, in particular the European Social Fund (ESF) Operational Programme, which is part of the European Structural and Investment Funds (ESIF) Growth Programme for England in 2014-2020. The Programme's priorities are to increase labour market participation, promote social inclusion and develop the skills of the potential and existing workforce. In particular in the context of Talent Match, it contributes to improving youth employment by providing support for young people who are harder to reach.

It incorporates Youth Employment Initiative (YEI) money to support youth employment in areas with higher rates of youth unemployment. The YEI aims to help young people who are not in employment, education or training towards sustainable employment, with a particular emphasis on apprenticeships, traineeships, job placements and further education leading to a qualification. It may be considered as complementary to other actions undertaken at national level in this regard.

The YEI shared several similarities with Talent Match in that it was geographically targeted at areas of highest need, involved the establishment of local steering and operational groups to guide activity - often building on existing local partnerships and emphasised bring together different providers to meet the varying needs of NEET young people (Some Talent Match partnerships have been in receipt of YEI funding and explicitly worked with the funding streams to expand Talent Match provision) (Ecorys, 2017).

In addition to mainstream UK Government funding there were a range of local initiatives of relevance to youth employment funded by local authorities, City Deals, Devolution Deals and Employment Support Innovation Pilots, as well as initiatives led by major third sector organisations such as the Prince's Trust, Business in the Community and others. A specific example of such an initiative is MyGo, which was an integrated employment and skills programme, designed to tackle youth unemployment in Suffolk, established as part of the Greater Ipswich City Deal. It aimed to provide more effective support for young people to enable them to make informed decisions about their future and move towards and into sustainable employment. Key elements included co-location of Jobcentre Plus services with additional employment support in order to provide a personalised and more intensive support offer, collaborative partnership working to facilitate access to a wide range of support options, 
and an offer of a range of different pathways towards the labour market, tailored to young people's needs and aspirations.

The evaluation of MyGo (Bennett et al., 2018) highlighted several themes that chime with the Talent Match experience, including: the importance of effective partnerships, collaborative leadership and good governance at both strategic and operational levels; the value of effective joining up of provision across partners; the quality and seamless nature of coaching support that many young people indicated was crucial for successful outcomes; an in-house employer engagement team to enhance the MyGo offer; and the fact that two-fifths of participants were not claiming benefits at the point of referral.

Interviews with national policy stakeholders during the course of the Talent Match National Evaluation confirmed a general acceptance of a direction of travel in youth employment policy (and employment support policy more generally) towards localism. They highlighted several examples of effective local partnerships which offered clear and well-coordinated services to young people. However, there were concerns around a 'proliferation of local initiatives' leading to a 'crowded landscape' and possible 'confusion' or 'duplication' of support, whereas national programmes can avoid 'postcode lotteries' and are more clearly designed and delivered than local ones.

\subsection{Changing youth transitions and the labour market case for Talent Match}

\section{Developments in education, training, apprenticeships and traineeships}

At the time that Talent Match was conceived and in the period when it was operational there were several important policy changes relating to education and training. A range of policies were designed to encourage young people to continue in education or training: The Raising the Participation Age in 2013 requiring young people to continue in education or training until their $18^{\text {th }}$ birthday; From the $2014 / 15$ academic year all students starting a new study programme of 150 hours or more, aged 16 to 18 years who did not hold a GCSE grade $A^{*}$ to $C$ (new GCSE 9 to 4 or equivalent) qualification in mathematics and/or in English, were required to be studying these subjects as part of their study programme in each academic year. Also highlighting the importance of qualifications, the Adult Education Budget provided free training for 19-23 year olds to attain their first full qualifications at Level 2 (GCSE or equivalent) or Level 3 (A level or equivalent), free training for those aged 19 and over up to and including Level2, and free English and Maths training up to Level 2 for anyone who has not achieved that level.

Over the period that Talent Match has been operational a key thrust of Government policy has been to expand apprenticeships and traineeships. Apprenticeships involve paid employment and are seen as a means to address the transition to work for young people not taking the higher education route. Importantly in terms of attractiveness of apprenticeships for young people living independently the apprenticeship wage rate in the first year is below the national minimum wage for their age group. Traineeships are targeted at young people who have not been employed and who have little work experience. They are concerned work preparation and work experience. A young person on a traineeship they can receive benefits.

\section{The changing labour market and implications for young people and Talent Match}

Since the late 1970s there has been a marked sectoral shift in the structure of employment from manufacturing to services. The labour market has continued to change over the last decade - including in ways that disadvantage young people (UKCES, 2012). 
Typically young people are disproportio nately concentrated in sales and elementary occupations. These occupations are characterised by low pay and were hard hit in recession. By contrast employment growth has been concentrated in higher level nonmanual managerial, professional and associate professional occupations which are less likely to be filled by young people. Young people employed in such occupations are overwhelmingly graduates. Hence labour market change has resulted in fewer opportunities for disadvantaged young people and so their tr ansitions to work are more difficult.

There has also been a shift in the size structure of businesses in the direction of fewer large businesses (with 250 or more employees) and more microbusinesses. Smaller businesses are less likely to have formal HR structures and recruitment and selection processes than large businesses. They are also more likely to emphasise the importance of experience when recruiting and to use informal rather than formal recruitment methods. Informal connections tend to be built up over time and through experience of work. Hence this change in the structure of businesses disadvantages young people. There is evidence that the proportion of young people combining learning and earning has declined over the last two decades (Conlan et al ., 2014). Yet the emphasis placed by employers on experience results in the 'Catch-22' situation for young people: they find it difficult to get a job without experience and without a job they find it difficult to get experience. With work experience becoming a more important component of employability, there was a clear labour market case for work experience to be part of the Talent Match offer.

There is little chance of gaining opportunitiesfor work experience and improving young people's employment rates without working closely with employers. Consistent feedback from employers reported in evidence to the House of Commons Work and Pensions Committee enquiry on 'Employment opportunities for young people' (WPC, 2017) has been that Jobcentre Plus requirements for young people to apply for a significant number of jobs via Universal Jobmatch has led to large volumes of applications from unqualified candidates. This was irritating for employers and unhelpful for young people. Again, there was a clear labour market case for employer engagement, to focus on a good match between employer needs and a young person's skills and attitudes.

\subsection{Conclusion: comparators for Talent Match}

The Fund invested $£ 108$ million in Talent Match to address unemployment amongst 18-24 year olds. It was delivered between 2014 and 2018 through partnerships in 21 Local Enterprise Partnership areas in England. The programme sought to support young people who are furthest from the labour market through personalised, nonstandardised provision which addresses their needs and aspirations.

The labour market and policy evidence presented in this chapter indicates that young people were disproportionately affected by the 2008 recession and those facing the most disadvantage have been most impacted by ongoing labour market changes. Over the last forty years a range of mainstream national programmes have sought to support young people into work. The Work Programme was the mainstream programme (covering young people and other age groups) operational at the same time as Talent Match and so is an obvious comparator. However, there are important differences between Talent Match and the Work Programme (as outlined in Chapter 2) in terms of ethos and the contrast between a voluntary and a mandato ry programme. Talent Match was also a vastly smaller programme, geographically and financially.

In terms of focus on areas of highest unemployment and the most disadvantaged, an emphasis on local partnership working and joining up local provision, the YEI shares several similarities with Talent Match. However, the fact that some Talent Match 
partnerships used YEI funding to complement and extend their activities, together with the fact that there is less evaluation information available than for the Work Programme, makes it a more challenging comparator. Hence in subsequent chapters the Work Programme is used as the primary comparator for Talent Match. 


\section{Comparative models: a strategic perspective}

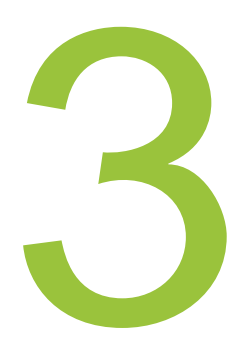

This chapter provides an assessment of Talent Match vis-à-vis other programmes from a strategic perspective. It considers underlying models for youth employability programmes. It then sets out the strategic objectives, rationale and ethos of Talent Match - including its voluntary nature and co-design with young people as a central principle. It outlines the main features of the governance of the programme and introduces the underlying partnership model (which is the subject of further exploration in subsequent chapters).

\subsection{Models and paradigms underlying youth employability programmes}

In terms of the broad approach to employability programmes taking an active approach to help those out of work to find work there are two models:

- Work First - prioritising entry to work at the earliest opportunity. The main emphasis of this approach is on job search assistance, short-term work preparation activity, targeted short-term work experience and support to help with barriers to work such as transport, clothes and tools for jobs.

- Human Capital - seeks to increase skills and qualifications - including through longer-term training leading for acquisition of formal qualifications - to reduce the effects of human capital related disadvantages that individuals face before assisting them to find work.

3.2. The strategic objectives, rationale, ethos and governance of Talent Match

\section{Objectives and rationale}

As outlined in the previous section, in the context of high levels of youth unemployment in the Great Recession, the Talent Match programme sought to support young people who were furthest from the labour market through personalised, flexible provision addressing their needs and aspirations. 
The Programme Guide for Talent Match (Big Lottery Fund, 2012) set out the principles the programme was to follow to "enable thousands of young people to lead successful and fulfilling lives":

- Structured opportunities: bringing together the public, private and voluntary and community sectors to create effective partnerships and coordination at the local level.

- Supporting local solutions: matching the supply of talented young people to local demand for employment and enterprise

- Asset-based: a belief in people-powered change and the ability of young people to improve their own circumstances and life chances with the right support. This was the rationale for the engagement and involvement of young people in all aspects of Talent Match activities: co-design by, and co-delivery with, young people were essential tenets of Talent Match. This belief also underpinned the objective of promoting positive images of young people.

\section{Local partnership working: ethos and governance}

The Programme Guide objectives highlight partnership working as a key feature of Talent Match. Talent Match is not unique in this regard, but it is distinctive in terms of the explicit nature of the emphasis on partnership working. Mainstream employability programmes operational at the same time as Talent Match were characterised by market-based operations and payment by results characteristic of New Public Management. The underlying spirit of Talent Match was embedded in partnership working principles. The rationale was that involving otherwise independent bodies / organisations / agencies with common objectives via collaborative working - both horizontally and vertically - in a relationship characterised by at least some degree of trust, could produce more flexible/ innovative policy solutions by bringing together complementary expertise, aid joining up across policy domains.

Talent Match partnerships varied in size and structure but in essence they were interorganisational collaborative relationships. They were distinctive in terms of the scale and role of the voluntary sector as a lead partner, acting as an accountable body for the funding and putting in place effective governance arrangements for the programme by convening a wider strategic partnership and commissioning delivery partners to deliver Talent Match activities (whether on a grant basis, a payment by results basis or a spot purchase arrangement). The strategic partnership typically involved senior of ficials from local authorities, the LEP, an education/training provider, Jobcentre Plus, the police, local employers and young people. The breadth and influence of this strategic partnership marks out Talent Match from mainstream youth employability programmes.

An understanding of the need for local solutions is not exclusive to Talent Match, but the emphasis on being responsive to local conditions and to the needs of particular sub-groups and individuals in placing primacy on the "matching" and "fit" of young people to opportunities available locally arguably is greater than in some other programmes; (MyGo - outlined in Chapter 1 - is an exception here). At least in part this reflects the central role of young people in Talent Match which is inherent in the distinctive asset-based approach, with young people involved in co-designing the programme as a core principle.

This ethos is reflected in the results of a Talent Match partnership survey which highlighted the three most significant factors which informed the design of Talent Match projects as being young people, partner organisations and local data gathered by the partnership (identified by 17, 14 and ten, respectively, out of 20 respondents). 
In successive surveys of Talent Match partners, partnerships were overwhelmingly positive about young people's involvement is assisting delivery across a range of activities from marketing, to local evaluation, engagement and dissemination, to membership of core partnership committees and involvement in management and commissioning of services. Several interviewees during partnership visits highlighted the important contribution made by young people in bringing a different dynamic to partnerships. The 'lived experience' of young people seeking employment helped shape the nature and delivery of Talent Match activities.

A further distinctive feature of Talent Match is the test and learn ethos. The (active) contract management approach meant that the Fund provided critical challenge to partnerships at key stages in their lifetime, as did the governing bodies of partnerships (including local organisations and young people). The partnership managers were able to redirect their focus in accordance with their experience and learning and changes and opportunities arising in the external environment. In a partnership survey, 15 out of the 21 partnerships indicated that during the course of delivering Talent Match they had changed some of the ways in which their services/activities were delivered.

\section{Voluntary versus mandatory participation}

Importantly, participation in the Talent Match programme was voluntary. This marks it out from mandatory active labour market programmes such as the Work Programme and the Youth Obligation where participation was mandatory for most participants as a condition of benefit receipt. In practice, as outlined in a subsequent section on 'Engaging participants', this meant that participants were recru ited to Talent Match via a range of routes. Hence, in strategic terms (within the geographical areas within which it operated) the pool of young people who were within scope of Talent Match was larger and more diverse than for mandatory programmes. Indeed, a key objective of Talent Match was to engage with young people beyond the gaze of official statistics and so outside the remit of mandatory programmes.

The voluntary nature of the programme also meant that participants could leave the programme when they chose to do so without fear of sanctions. This meant that the young people participating in Talent Match exercised choice in a manner that they could not in mandatory programmes. In practice, young people engaging in Talent Match who had experience of mandatory programmes tended to be positive about the voluntary nature of the programme and about the support that the key workers could offer them.

\subsection{Conclusion: strategic assessment of Talent Match in a comparative perspective}

While Talent Match was a youth employability programme, in that it sought to support young people who were furthest from the labour market and to match supply and demand, it was also more than this. It was a holistic programme too, in that it placed emphasis on non-employment needs and goals also. The relative attention placed on employment- and non-employment needs varied - including by individual and key worker. The intention was that Talent Match activities planned to deliver employment and non-employment goals should be mutually reinforcing, rather than separate. Hence, from a strategic perspective Talent Match may be considered as a 'Youth Employability Plus' programme.

Given its 'Youth Employability Plus' status, it is perhaps not surprising that Talent Match does not fall neatly into either of the 'Work First' or 'Human Capital' approaches to employability programmes. Arguably it was closer to a 'Work First' than to a 'Human Capital' approach, albeit without some of the starker elements of the former, which 
have been criticised as pushing individuals into low-paid poor quality jobs. The relational and individualised ethos of Talent Match meant that key workers worked closely with young people to identify courses of action and outcomes that were relevant to them. Some individuals wanted, and benefited from, 'Work First' CV preparation and job search support to enter work. For some individuals an initial job might not have been the one that they desired, but key workers emphasised that such a role could form a 'stepping stone' to a preferred job/ career. Other young people used Talent Match support to sort out their lives and clarify their options and then worked towards longer-term training and education courses, but these were in a minority. 


\section{Programme design at the direct contract level}

This chapter compares the commissioning process and overall programme design for both Talent Match and the Work Programme. It focuses on the level of 'direct' contracts between the relevant funder and the organisations responsible for any further contracting. In the Work Programme these direct contracts were with the 'prime providers' or 'primes', and in Talent Match the 'partnership leads'. The first section contrasts the fundamentals of the two programmes, including contract size, length and geographic coverage. The chapter then explores the commissioning process for both primes and partnership leads, as well as the differences between the two sets of providers. The payment model and outcome measures of the two programmes are then contrasted, which leads to a consideration of the respective resources available to providers. Finally, the roles of various forms of performance management and accountability measures are considered in both programmes.

\subsection{Programme size and coverage}

The Work Programme was an extremely large, national programme. The National Audit Office estimated in 2014 that the final cost from payments to contractors would be approximately $£ 2.4$ billion by the end of the programme (NAO, 2014). England, Wales and Scotland were divided into 18 'Contract Package Areas' (CPAs), each with two to three prime providers. These primes were contracted directly by the DWP to provide employment services to the long term unemployed. In total the DWP awarded a total of 40 contracts to 18 prime contractors. This represented a consolidation of provision from several different predecessor schemes into a smaller number of large prime contracts. The intention was to reduce the DWP's transaction costs, allow economies of scale, and alongside the 'payment by results' payment model discussed below, transfer risk away from the DWP (Finn, 2011; Considine et al., 2018). Primes did not have to deliver the entire programme on their own, however, and could optionally subcontract out parts of their provision. Approximately 500,000 18-24-year olds were successfully referred to the programme over its lifetime. Unlike Talent Match the Work Programme was not limited to this age group, however, and its total case load, including all types of users, was over 1.9 million people.

Talent Match was a vastly smaller programme, geographically and financially, even compared only to just the Work Programme's provision to 18-24-year olds. The Fund provided £108 million, divided amongst 21 partnerships. By the end of December 2018, Talent Match had worked with 25,885 young people, based on the number who had filled out the compulsory baseline survey at the start of their involvement. Although small compared to the Work Programme, in the context of a voluntary sector led programme, funded by the Fund, Talent Match can be considered a relatively large scale investment. The contrast with the scale of the Work Programme, however, should highlight the limits to what Talent Match could reasonably be expected to achieve in terms of societal or area level outcomes. 


\subsection{Length of contracts}

Compared to previous national employment programmes, the Work Programme contracts were higher in value and ran for a relatively long period, from June 2011 to April 2017. The DWP hoped the security of these long contracts would allow providers to develop expertise and encourage them to invest in their capacity. On the other hand, economic conditions shifted significantly over the course of the programme, which meant that some of the initial financial and performance assumptions quickly became unrealistic (NAO, 2014). Notably, referrals for some groups proved lower than expected and decreased as the labour market gradually improved (Foster et al., 2014). There was also a shift towards a higher proportion of Employment Support Allowance claimants, who typically faced higher barriers to work.

Talent Match ran over an overlapping timeframe to the Work Programme, from January 2014 to the end of December 2018. As such, it was subject to similar advantages and disadvantages. The long time period provided an extende d period of stability for the provider organisations in a period of ongoing public sector austerity, especially in related areas such as youth work. On the other hand, local economic conditions were not static and largely improved over the period. A benefit of the Talent Match approach was that a high degree of flexibility (through 'test and learn') was designed into the programme to cope with this change, as discussed in Chapter Six.

Another implication of the longer contracts was that there was little scope for turnover amongst the direct contractors or new market entrants. One Work Programme provider, Newcastle College, did exit the market as its contract was taken away by the DWP due to a low outcomes rate, but there was otherwise no change to the line-up prime providers once appointed Some providers were bought out by other organisations during delivery, however, and there was greater change at the subcontractor level. Similarly, no Talent Match partnership leads had their funding removed, although one partnership returned part of its funding following the two-year review point, in part due to other sources of youth unemployment provision becoming available in the same area.

\subsection{Commissioning process}

The Work Programme's contracts were put out to tender through a public commissioning process that appeared to be dominated by an emphasis on price (NAO, 2012). In order to bid for prime contracts, organisations had to first meet several financial criteria to demonstrate they had the financial capacity to deliver such a large programme under a payment by results finance model. Primes were also able to offer 'discounts' on the published payment rate per job outcome, the size of which appeared to make all the difference to winning contracts (Simmonds, 2011).

Commissioning for Talent Match provides a marked contrast, although there is comparatively little published on the process. The Fund specified in its 2012 strategy that one of its five large strategic investments would be aimed at tackling youth unemployment. The 2010 Coalition Government had recently set up Local Enterprise Partnerships (LEPs) across England, each combining several local authorities and with a remit to set local economic priorities and drive growth, jobs, infrastructure and skills. The Fund subsequently chose 21 of these LEP areas, across England, each with high numbers of young people unemployed for over a year, through which to deliver Talent Match.

Local authorities in those areas were invited to help the Fund identify a suitable voluntary organisation to act as the lead delivery partner. Once appointed, partnership leads were then required to submit a bid to the Fund, outlining their approach to 
partnership and delivery. In most cases this involved establishing a wider delivery partnership, either from scratch or based on an existing network within the area. Following feedback from this initial bid, there was a substantial, yearlong development phase, in which partnerships were able to work up their business case before a final allocation of funds.

The commissioning process for Talent Match was therefore quite lengthy, running from October 2012 to the end of 2013. This provided some challenges, such as staff turnover and relatively high start-up costs. It stands in marked contrast to the Work Programme, which was designed and implemented in record time and in fact received some criticism over the lack of time available to prepare bids (NAO, 2012). The overall process for Talent Match appears to have been much more discursive and deliberative compared to the rigid bidding requirements of the Work Programme. On the one hand this allows greater flexibility and sensitivity to local requirements, as well as greater potential to work through any problems or issues. On the other, it comes at a potential cost in terms of transparency and the speed of the commissioning process.

\subsection{Geographical coverage}

The 18 Work Programme CPAs were based at the regional level across England, Wales and Scotland. As a national, universal programme, primes needed to cover wide areas inclusively, both rural and urban. A common subcontracting arrangement was to divide these large areas into smaller subregions, divided up amongst subcontractors (Rees et al. 2013).

Talent Match, conversely, was a much more geographically targeted programme. As described above, the 21 LEP were chosen largely based on having high numbers of 18-24-year olds out of work. Reflecting the underlying LEP areas, some of the partnership areas were much wider geographically than others. Seven partnerships covered just one or two local authority districts, six covered three or four districts, and eight covered five or more.

The claimant rate for each LEP is a reasonably strong predictor of whether it was featured in the programme ${ }^{2}$, but it should be noted that if selection were based purely on this measure, three of the included LEPs would have been replaced, predominantly by more rural areas.

Indeed, the final coverage of the programme shows a slight prevalence of urban over rural areas. Of the 21 partnership areas, 11 were classified by the evaluation team as predominantly urban, just one predominantly rural, and nine were a mixture of urban and rural areas. Furthermore, $92 \%$ of Talent Match participants lived in an address classified as 'Urban' by the Office of National Statistics (ONS), including both cities and small towns. By comparison, however, the ONS (2019) estimate that approximately $87 \%$ of $15-29$-year olds in England live in urban areas, so arguably this urban focus is not too unrepresentative of the national picture.

In addition to the selection of the 21 LEP areas, however, Talent Match also in itially placed an emphasis on geographic targeting within partnership areas. Specific wards were identified with 'hotspots' of youth unemployment and high levels of NEETs. It was originally envisioned that young people would be recruited only from within these areas. In practice, the level of spatial targeting varied amongst partnerships and this original focus weakened over the course of the Programme. The evaluation team identified four main geographic approaches. Ten partnerships proceeded with the idea of targeting specific wards, and one went further by identifying specific estates. In two

${ }^{2}$ A correlation of .63 
partnerships, a mixture of both specific wards and entire local authority districts were targeted. In the remaining eight, a geographically targeted approach was not taken, though in some cases there were recruitment 'hubs' at particular locations.

In line with the test and learn approach of Talent Match, the commitments to geographical targeting evolved. Arguably, youth unemployment was not as tightly focussed geographically as first assumed. In practice Talent Match partnerships were understandably unwilling to turn away young people who would benefit from their services, and in some cases meeting their recruitment targets would have been difficult if these restrictions were strictly maintained. The contrast with the universal coverage of the Work Programme highlights the issues of equity and prioritisation that inevitably accompany a more targeted approach. Potentially, resources can be targeted at those who need it most, but equally others who could benefit might miss out on support.

\section{5. $\quad$ The lead providers}

In each LEP area, a partnership lead was appointed in each area to be directly accountable to the Fund, overseeing the grant management process and coordinating delivery partners. In this respect, partnership leads fulfilled a similar role to 'prime providers' on the Work Programme, albeit in a different context. The partnership leads broadly corresponded to four different types of organisation. These included national VCS organisations (seven areas - five of which were led by the Prince's Trust), local infrastructure organisations (six areas), local specialist VCS organisations (six areas) and consortia-based organisations (two areas). All were from the voluntary sector, though the different types are likely to differ significantly in terms of their background and wider context. Notably, the Prince's Trust played a unique and substantial role within Talent Match, as the only organisation to act as a partnership lead in more than one area. In several areas it was able to utilise its existing, nationwide network of provision. Overall, it supported 19 per cent of the young people participating in the programme.

Classifying the Work Programme providers, in contrast, is challenging, given that these were extremely large organisations, several of whom have since merged, gone into administration, or expanded further into the broader public service contracting field. A few of the contracts were won by training providers or recruitment agencies, but a large majority of the primes were public sector contracting specialists, with varying degrees of specialism in the welfare-to-work field. Only 8\% went to new entrants (G4S and JHP Group) (Simmonds, 2011). Simmonds noted that 36 per cent of claimants were expected to flow through two providers (Ingeus Delloitte and A4e), and over half (53 per cent) through four (Seetec and Working Links as well). All Work Programme Primes had to have an annual income of at least $£ 20$ million in order to bid for their contracts.

The most obvious contrast with the Talent Match partnership leads was that 88 per cent of the Work Programme contracts were awarded to private sector organisations. There was voluble concern within the policy debate at the start of the Work Programme that previous voluntary sector providers had been 'squeezed out' of direct contracting (WPC, 2011). 13 of the 16 partnership leads were charities, and the remaining three were varieties of social enterprise. As discussed in Chapter 3, Talent Match therefore stands in contrast to the Work Programme as an explicitly Voluntary Sector led programme.

Talent Match lead partnerships were also generally smaller than the Work Programme's $£ 20$ million threshold. Again, however, there is huge variation. Both the Prince's Trust and the Shaw Trust had incomes over $£ 20$ million in 2014. Two had incomes below $£ 20$ million but over $£ 10$ million, and a further ten had incomes lower than $£ 10$ million but over $£ 1$ million. Only two had incomes less than this. It is worth 
noting, therefore, that whilst Talent Match lead partners are, on average, smaller than their Work Programme counterparts, they are very large by Voluntary Sector standards. For context, the National Coalition of Voluntary Organisations identifies 97 per cent of all 'general charities' as having an income below $£ 1$ million, and 82 per cent less than $£ 100,000$ (NCVO, 2019).

\subsection{Provider competition}

In theory, one of the advantages of outsourced public services such as the Work Programme is that competition between providers will stimulate innovation, efficiency and greater effectiveness. There are, of course, also risks that cooperation is undermined (Considine et al., 2017). As described above, competition in the Work Programme occurred, firstly, at the bidding stage via the 'discounts' primes could offer from the standard payment rates. Post contract award, however, there was also a contract mechanism to ensure competition between the two or three primes operating within the same area. The DWP could shift market share, in the form of new referrals, from the lowest performing prime to the best performing prime. It did this at least three times, shifting $5 \%$ of referrals in $10 \mathrm{CPAs}$, with differences of at least 10 percentage points in performance (WPC, 2013).

Talent Match, in contrast, did not feature substantial competition and was set up instead with partnership as a guiding design principle. Partnerships did not overlap geographically, precluding any direct competition. As well as lead partners and delivery partners, partnerships were encouraged to include stakeholders from the public and private sector within their wider strategic partnerships and to act cooperatively as an important part of their local youth unemployment field. More detail on the partnership approach is available in a previous evaluation report (Damm et al., 2018).

\subsection{Payment model}

The financial model of the Work Programme was largely structured around the principle of 'payment by results'. Compared to previous programmes prime providers received very little funding upfront. The amount differed between different 'payment groups', which differed on the age, referral route, and particularly the benefit type of each service user. A $£ 400$ 'attachment fee' was initially received for those on jobseekers' allowance aged 18-24, but this was phased out as the programme progressed (WPC, 2013). This relatively small payment constituted only between ten per cent of the funding available for each service user. The remainder was available only following an employment outcome. The maximum payment for 18 to 24 -year-olds on Job Seekers Allowance was $£ 3,810$. This includes the attachment $£ 400$ fee, a job outcome payment of $£ 1,200$ and maximum sustainment payments of $£ 2,210$.

The Work Programme was unusual compared to predecessor schemes not only due to the degree of emphasis on payment by results, but also on the requirement for employment to be sustained to count as a job outcome (Finn, 2011). This aimed to address concerns that previous schemes had been placing users into short term and unstable jobs. Even an initial job outcome was paid only if employment was sustained for 13 or 26 weeks, again depending on the payment group. Most of the available payment was only paid in four-weekly instalments if employment continued to be sustained, up to a maximum of 24 months.

Talent Match was set up under an entirely contrasting funding model. The programme was allocated $£ 108$ million in funding. As with the choice of the 21 partnership areas, the division of this funding between the partnership leads was based on multiple criteria. An initial, indicative allocation was made based on levels of youth 
unemployment in each area, but this was subject to amendment depending on the business case made by the partnerships. Once the funding level was determined and delivery began, however, it remained fixed and was not based on payment by results. This means that partnership leads bore substantially less financial risk than their Work Programme counterparts and their service's financial viability was not dependent upon the total of their employment outcomes. This should have allowed them greater flexibility to experiment and innovate without risking severe financial consequences (discussed in Chapter 6).

The size of the grant allocated to each Talent Match Partnership varied significantly. The smallest grant was to Stoke-on-Trent and Staffordshire (£990k) and the largest was to the Black Country ( $£ 10.3$ million). The amount was not based on any single formula but appears most closely correlated with the target each partnership was initially set for the number of young people the Partnerships worked with over the course of the programme ${ }^{3}$. It appears slightly less correlated with each partnerships' initial employment target, or the 18-24 claimant rate in each area as of June $2014^{4}$. It should be borne in mind that partnerships will also have differed in terms of the delivery model outlined in their bid, their proposed targeting strategy, and their local context.

On Talent Match, a job outcome was defined as either self-employment, working 16 hours or more per week, or fewer than 16 hours per week if caring responsibilities, education or health and disability limited their maximum working hours. A sustained job outcome was defined as six or more months of employment, or 12 months of self employment. Talent Match's aim was to improve young people's pathways into 'secure, meaningful employment or enterprise'. Unlike the Work Programme, this places an emphasis on the quality of the employment, though this is not explicitly included in the core definition of a technical job outcome. Ensuring job quality was therefore devolved to partnerships. Arguably, Talent Match also placed a weaker emphasis on sustained employment compared to the Work Programme, which required three to size months of employment to qualify as any outcome at all.

\subsection{Performance management}

The DWP set demanding minimum performance targets for Work Programme prime providers. These target employment rates were set at ten per cent higher than the DWP estimated would have occurred without the Work Programme, higher than had ever been achieved by predecessor programmes during economic boom years (WPC, 2011). For 18-24 year olds, the minimum performance target was set at 5.5 per cent for the first year, and at 44 per cent for subsequent years, until the programme case load started to wind down (WPC, 2013). The Work and Pensions select Committee noted that after the first year, all the prime providers had missed the target and were in technical breach of their contracts, although this improved over later years, at least for non-disability benefit related groups (Foster et al., 2014).

Talent Match partnerships were also set individual employment targets. In total these amounted to a programme wide target of 8,100 job outcomes, or 28 per cent of the target caseload. Partnerships were also set targets based on the number of young people engaged, as measured by the number who filled out the initial 'baseline' questionnaire. Overall, Talent Match aimed to engage over 29,000 18 to 24 -year olds over the life of the programme. As discussed, the relationship between the target number of beneficiaries, the target employment rate, and the grant size is not particularly strong. This suggests that funding and targets were allocated more on a

\footnotetext{
${ }^{3}$ A correlation of 68 . Some partnership's targets were increased over the course of the programme.

${ }^{4}$ Correlations of .54 and .38 respectively
} 
qualitative basis in response to the business plan presented, rather than by a set funding formula or payment model.

In terms of contract management and the pressure to meet targets, the experience of both primes and partnership leads will differ between organisations and individuals (Foster et al., 2014). Nor is it possible to draw a clear dividing line between the more formalised performance management approach of the DWP and the more partnershipbased approach practiced by the Fund. The Work Programme evaluation identified that project managers tried to avoid an adversarial approach and more punitive measures were seen as a last resort. In many cases primes reported an open and constructive relationship (Foster et al., 2014). Nevertheless, the DWP did shift market share between providers, terminate a prime contract, and subjected worse performing primes to a more intensive management regime (Foster et al., 2014). It was also generally perceived that performance management became more intensive as the programme developed and external pressure on the programme increased.

The targets set by Talent Match do not appear to have been as stringent as those set by the DWP and the approach to project management was generally collaborative. The main mechanism for reducing or terminating funding was a two-year review clause. In practice, no partnerships lost their contract, although as mentioned above one partnership did return part of its funding following the review. Grants and performance were managed on an ongoing basis, but partnerships were not subject to the automatic, contractual enforcement measures seen in the Work Programme. The absence of payment by results meant there were no other serious financial consequences for missing targets. Nevertheless, throughout the programme, the partnerships did appear to be actively aware of their target. There is the possibility that fear of enforcement influenced behaviour, even without any punitive actions in practice.

As with all programme design features, there are potential advantages and disadvantages to more or less intensive performance management. Unsurprisingly, the stronger the enforcement of targets, the greater lengths providers will go to meet them (Rees et al., 2014). This can lead to unintended consequences, however, if providers seek to game the system to achieve largely hollow outcomes, such as placing people into low quality, high turnover jobs. These may technically meet the contract criteria but contradict the intended aims and values of the programme. Examples within employment services include pushing jobseekers into poor quality or unsustainable employment, or rationing provision to those already closest to the labour market (WPC, 2015). The extent to which these undesirable outcomes did or did not occur during Talent Match is discussed in Chapter 6. Overall, however, a comparatively low degree of risk was passed onto partnerships compared to primes, and accountability was largely monitored via an engaged grant making processes.

\subsection{Soft outcomes}

The debate on employment services often features calls for 'soft outcomes' to be measured as well as 'hard' job outcomes (WPC, 2011, 2013; Foster et al., 2014). This sometimes includes intermediate, 'non-job' outcomes that nevertheless mark the removal of a significant barrier to employment. Intermediate outcomes include new qualifications, long term training, volunteer placements, improved housing, greater confidence or improved mental health (Aiken, 2007). The proposed advantage to measuring these factors is that providers are recognised or rewarded for work that they put into helping users move closer to the labour market, even if this does not lead immediately to a job outcome. The challenge is that these 'distance travelled' outcomes can be complicated to measure or verify, let alone use as abasis for targets or outcome payments. These milestone outcomes do not appear to have been systematically measured as part of the Work Programme but have been to some extent recorded as part of the evaluation of the Talent Match programme. 
Talent Match reported on a series of measures known collectively as the 'scorecard'. As well as job outcomes and sustained job outcomes, these measures included the numbers of young people volunteering, regularly volunteering, in basic skills training, in work experience, in apprenticeships and in formal education. Although only a subsection of all possible 'soft outcomes', these measures were not only systematically recorded but regularly reported to the Talent Match board. On the other hand, recruitment and employment outcomes were the only outcomes for which targets were set, which arguably implied their primary importance to the Fund. Partnerships do not appear to have been as aware of or concerned about these 'soft' outcome totals, compared to the hard employment outcomes target, but this does not necessarily mean that they did not prioritise them during delivery.

\subsection{Resources per participant}

As well as the headline amounts, it is important to consider the amount of funding available per programme user for the provision of services. As the Work and Pensions Select Committee (WPC) explains (2013), payment by results can make the headline payment levels for job outcomes in the Work Programme misleading. The total payment available for jobseekers aged 18 to 24 was $£ 3,810$, prior to the removal of attachment fees in 2014. Not all the participants referred from this group, however, would trigger an outcome payment. This means that the funding for those who did would have to partly fund the provision for those that didn't. The funding available per person would, therefore, be significantly lower in practice than the payment rate per outcome.

The Learning and Work Institute (formerly Inclusion) have modelled the finances of the Work Programme at several points. In the run up to the Work Programme launch, it was identified that the funding model for the Work Programme was extremely tight (Bivand, 2011; Mulheim, 2011), particularly for the groups with the highest potential barriers to employment (Simmonds, 2011). A report by Bivand and Melville in 2016 suggested that the DWP had paid an average of $£ 1,214$ for each participant referred to the Work Programme (across all payment groups), but that this was likely to change by the end of the programme due to ongoing sustainment payments. An earlier report on ESA claimants specifically (Riley et al., 2014), whose outcome rate was likely to be lower, suggested that payments for these groups could be as low as £690 per user, though again this was likely to change as the programme proceeded. As discussed further in the following sections, there was a high risk that providers would simply not have the resources to deal with issues such as mental or physical health conditions.

Although the grant size of each Talent Match partnership is reasonably strongly related to the number of young people targeted, there remains substantial variation in the resources available per participant. By the end of the programme this had varied overall from as little as $£ 2,000$ per beneficiary to as high as $£ 11,300$ (Wilson et al., 2019). The amount available per participant is not obviously related to any other obvious predictors, such as the deprivation of the areas where young people lived, the local claimant count, or the employment and engagement targets set for each partnership. This suggests it was largely a feature of the activities outlined in partnerships business plans. In all cases, however, the amounts available appear to significantly outstrip the resources available on the Work Programme. The average amount per young person on Talent Match, from any partnership, was around $£ 4,000$.

The Work Programme evaluation does not appear to provide any general statistics on the size of caseload per personal advisor, but survey responses suggested that they were higher than anticipated for mainstream jobseeker payment groups, particularly earlier in the programme. It references caseloads for one provider jumping from 60 to 180 (Lane et al., 2013). Talent Match delivery partners were surveyed for the third time in 2018. In this survey they were asked how many beneficiaries, on average, each full- 
time equivalent key worker worked with at a time. Of those who provided a number, the mean was 17 and the median 15, though the results went as high as 60 in some cases. These are relatively low averages, which may call into question how some partners are interpreting a 'key worker'. Nevertheless, it seems reasonable overall to infer that caseloads were lower for Talent Match compared to the Work Programme given the different resources available, meaning young people could potentially receive more intensive support and advice. 


\section{Programme design at the subcontracting level}

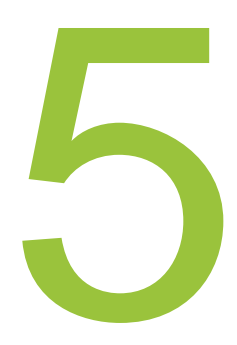

This chapter compares the subcontracting arrangements on both the Work Programme and Talent Match. Both programmes operated varieties of subcontracting, though in Talent Match subcontractors were referred to as 'delivery partners' in line with the overall partnership approach. The chapter firstly explores the extent of contracting in both programmes, before examining the subcontractors themselves. Further sections then cover the differing models of subcontracting, including the payment model for subcontractors and the bidding requirements. Finally, the relationship between primes and subcontractors, and partnership leads and delivery partners.

\subsection{Extent of subcontracting}

In discussing subcontracting arrangements, it is useful to distinguish between two types of provider. 'End-to-end' providers, including most Work Programme primes and Talent Match partnership leads, take on full responsibility for at least some programme users from the attachment stage through to the end of the users' involvement. Some subcontractors, however, operate on a call off basis, providing one-off or specialist provision to users. These are called variously 'specialist', 'tier two' or 'non-end-to-end' providers. Notably within the Work Programme, these non-end-to-end subcontractors received far fewer referrals than expected, largely reflecting the limited resources available to providers (Rees et al., 2013; Foster et al., 2014). Subcontracting within the Work Programme therefore occurred mainly to end-to-end providers, which is where most of the attention in the following sections lies. These providers are arguably also the most comparable to most Talent Match 'delivery partners'.

Work Programme primes were free to determine the degree to which they relied on subcontracting, though all subcontracted to some extent. Three of the primes subcontracted all their services, performing only contract management activities (Foster et al., 2014). Potentially, this allowed primes to focus purely on contract management without any conflict of interest towards their own provision. The remainder delivered varying proportions of service delivery themselves, which in contrast may have offered a greater understanding of frontline delivery.

Subcontracting was also a significant feature of Talent Match but occurred within the remit of Talent Match's explicit partnership model. Subcontractors providing service delivery were known as 'delivery partners', distinct from 'strategic partners' who contributed instead to governance, programme design, liaison with employers and other programmes, and strategic direction. Unlike the Work Programme, two partnership leads did not subcontract a substantial number of referrals to delivery 
partners and instead delivered almost entirely in house ${ }^{5}$. At the other extreme, as with the Work Programme, some partnerships passed all referrals to delivery partners. This occurred in some cases even where in-house capacity to provide delivery did exist.

The Work Programme evaluation stated that the number of end-to-end subcontractors near the start of the programme varied between two and 15, with an average of seven. It also found that for most of the prime contracts, the prime accounted for over half of the service delivery, with between 35 and 50 per cent remaining to be outsourced to other end-to-end providers. These subcontractors tended to cover a specific sub-area within the CPA (Foster et al., 2014).

Three Talent Match partnerships used a very wide network of delivery partners (over 20). This included Greater Manchester who operated a 'spot purchase' model, with 41 different delivery partners recorded by participants during their baseline interview. Overall, the median number of delivery partners was five, while the mean was ten. As with the Work Programme, geography played an important role in the size of the partnerships. Those covering wider areas unsurprisingly had a larger number of delivery partners. The key point is that variety prevailed in both programmes, in terms of the amount of delivery outsourced and the number of subcontractors.

\subsection{About the subcontractors / delivery partners}

A survey of Work Programme providers in 2014 found that just over half of all subcontractors (52 per cent) were small organisations, according to the number of their UK employees (50 or fewer). For end-to-end providers only, however, the figure was slightly lower at 42 per cent. Overall, despite providers originating in a variety of market sectors and some bringing different specialisms, the Work Programme appeared to benefit mid-sized and larger generalist providers (Foster et al., 2014; Rees et al. 2013). Generalist providers received more referrals and were better placed to weather variations in those referrals throughout the programme.

Comparison with Talent Match delivery partners is made challenging as the size of delivery partners was recorded using income, rather than employees as for the Work Programme subcontractors. Around half of delivery partners in 2014 (49 per cent) had an income over £1 million (41 per cent in 2015, 44 per cent in 2018). This suggests a relatively high average income compared to charities generally, though there was considerable variation in both directions. Delivery partners are generally quite local in the scope of their operations, however, with 25 per cent operating within particular neighbourhoods or communities in 2014 (27 per cent in 2015, 32 per cent in 2018), 37 per cent at a maximum of LEP or local authority level (31 per cent in 2015 and 2018), and the remainder operating regionally or more widely. In general terms, the picture for subcontractors in both programmes appears to be heterogeneity, with variation in size and background.

Perhaps the clearest point of distinction between both programmes lies in the sector of the organisations involved. There was significant concern around the initiation of the Work Programme that the voluntary sector was being 'squeezed out' of publicly funded employment services, despite a long history of involvement (WPC, 2011). Although this was largely the case at the prime level, subcontractor provision did contain a substantial number of voluntary sector organisations (40 per cent), only slightly fewer than the private sector (46 per cent) and more than the public sector ( 14 per cent)

${ }^{5}$ Based on analysis of CDF data. Only delivery partners with 10 or more referrals over the entire programme were included. 
(Foster et al., 2014). This applies to all subcontractors, although the breakdown for end-to-end provision only is similar (Rees et al., 2013).

In Talent Match, in contrast, a large majority of delivery partners in 2014 were from the voluntary sector (74 per cent, 80 per cent in 2015 and 2018). 17 per cent of delivery partners were from the private sector (12 per cent in 2015, 11 per cent in 2018), while nine per cent were public sector organisations (eight per cent in 2015, nine per cent in 2018). 22 per cent of delivery partners also had a background at in youth work (18 per cent in 2015, 19 per cent in 2018) as one of their two main areas of expertise and 23 per cent identified community development (27 per cent in 2015, 24 per cent in 2018). Whilst the Work Programme evaluation does not provide comparable data, at least a proportion of Talent Match providers therefore seem to have backgrounds quite distinct from the mould of generalised employment service providers. They arguably represent the types of specialised organisations which were squeezed out of direct Work Programme delivery, or ultimately received few or no referrals as non-end-toend providers.

\subsection{Model of subcontracting}

As well as the extent to which they wished to subcontract, primes had discretion over whether to introduce competition amongst their subcontractors or work more collaboratively in partnership (Foster et al., 2014). According to the Work Programme evaluation (2014), primes generally used both collaborative and competitive tools to drive subcontractor performance, generally with a larger emphasis on either one set or the other. Competitive measures included league tables, shifting referral shares between subcontractors and eventually removing contracts. The evaluation also notes, however, that Primes did not reallocate their own market share in this manner, regardless of performance (Foster et al., 2014). In many cases, however, supply chains were not set up to overlap geographically, which limited the potential for competition. Collaborative approaches, in contrast, included sharing best practice or labour market intelligence between providers and joint training events.

In contrast, as discussed, Talent Match was set up to operate as part of a more explicitly partnership-based model. Partnerships formed governing boards, incorporating representative young people and other stakeholders, though delivery partners were generally not included in order to ensure the board remained impartial. Nevertheless, there tended to be reasonable levels of agreement between the delivery partners over the delivery approach (Table 5.1 and Table 5.2). Over 61 per cent agreed that there was cross-partnership agreement on the delivery approach within their partnership (57 per cent in 2015,70 per cent in 2018). These results also seem to have improved over the course of the programme as partnerships bedded down into delivery. A majority also agreed that this agreement had assisted the delivery of their Talent Match partnership (52 per cent in 2014, 51 per cent in 2015 and 63 per cent in 2018). More detail on the partnership approach adopted by Talent Match is available in a previous evaluation report (Damm et al., 2018). 
Table 5.1: Extent to which there was Cross-Partnership agreement on delivery approach

\begin{tabular}{llll}
\hline & $\mathbf{2 0 1 4}$ & $\mathbf{2 0 1 5}$ & $\mathbf{2 0 1 8}$ \\
\hline $\begin{array}{l}\text { Strongly } \\
\text { agree }\end{array}$ & $15 \%$ & $22 \%$ & $34 \%$ \\
$\begin{array}{l}\text { Agree } \\
\begin{array}{l}\text { Neither } \\
\text { agree nor } \\
\text { disagree }\end{array}\end{array}$ & $21 \%$ & $24 \%$ & $22 \%$ \\
$\begin{array}{l}\text { Disagree } \\
\text { Strongly } \\
\text { Disagree }\end{array}$ & $3 \%$ & $10 \%$ & $4 \%$ \\
$\begin{array}{l}\text { Don't } \\
\text { know }\end{array}$ & $3 \%$ & $5 \%$ & $2 \%$ \\
$\begin{array}{l}\text { Not } \\
\text { applicable }\end{array}$ & $3 \%$ & $3 \%$ & $2 \%$ \\
\hline
\end{tabular}

Base 106 (2014), 115 (2015), 101 (2018)

Table 5.2: Extent to which Cross-Partnership agreement on delivery approach assisted or constrained development and delivery

\begin{tabular}{|c|c|c|c|}
\hline & 2014 & 2015 & 2018 \\
\hline $\begin{array}{l}\text { Greatly } \\
\text { assisted } \\
\text { delivery }\end{array}$ & $13 \%$ & $13 \%$ & $25 \%$ \\
\hline $\begin{array}{l}\text { Assisted } \\
\text { delivery }\end{array}$ & $39 \%$ & $38 \%$ & $37 \%$ \\
\hline Neutral & $26 \%$ & $28 \%$ & $26 \%$ \\
\hline $\begin{array}{l}\text { Constrained } \\
\text { delivery }\end{array}$ & $8 \%$ & $10 \%$ & $6 \%$ \\
\hline $\begin{array}{l}\text { Seriously } \\
\text { constrained } \\
\text { delivery }\end{array}$ & $3 \%$ & $4 \%$ & $1 \%$ \\
\hline Don't know & $4 \%$ & $6 \%$ & $1 \%$ \\
\hline $\begin{array}{l}\text { Not } \\
\text { applicable }\end{array}$ & $7 \%$ & $2 \%$ & $3 \%$ \\
\hline
\end{tabular}

Base 102 (2014), 114 (2015), 99 (2018)

\subsection{Subcontractor payment}

Work Programme primes also had discretion over how they paid their subcontractors and the extent to which they fully passed on the payment by results model. The 2014 survey of subcontractors reported on in the Work Programme evaluation indicated a wide variety of practices (Foster et al., 2014). 47 per cent of subcontractors were paid by results (sometimes including the attachment fee) and 26 per cent were paid via a flat rate service fee. 11 per cent were paid by some combination of the two models and 14 per cent were paid by an unspecified 'other' model (one per cent did not know). Much of the difference may reflect the difference between end-to-end and non-end-toend provision. In some cases the 'other' mechanism may also have indicated a 
softening of the payment model for some subcontractors, in order to keep their financial model viable (Foster et al., 2014). It should be noted that regardless of the payment method, primes are likely to retain some funding as a 'management fee' to pay for performance management and other related subcontracting activities. While Talent Match partnership leads might not use similar terminology, they too are likely to have retained some funding in order to manage the overall partnership.

Payments between the lead partnership and delivery partners also varied in Talent Match. Payment was mostly on a grant basis, but there were also cases of payment by results or spot purchase. This tended to reflect the lead organisation's expertise with different contracting models and the wishes of the partnership board or committee. 50 per cent of Talent Match delivery partners in 2014 were paid a fixed amount (51 per cent in $2015^{6}$ ), a model rarely if ever seen within the Work Programme. Seven per cent were paid by their caseload (also seven per cent in 2015). 27 per cent were paid using payment by results ( 26 per cent in 2015), which may largely reflect the approach of the Leeds partnership, one of the larger partnerships and with experience of operating payment by results systems in other programmes. 16 per cent reported 'other' as their payment method (also 16 per cent in 2015), including a combination of the previous methods. Again, variety predominates, though with a much lower emphasis on outcomes-based payments in Talent Match, as would be expected. In fact, the existence of any payment by results at all within Talent Match is arguably a surprising feature, which may indicate the way in which the public sector is able to set standardised 'norms' of behaviour in the wider field, beyond its own programmes.

\subsection{Relationships}

As the Work Programme evaluation points out (Foster et al., 2014) it can be difficult to generalise about subcontracting relationships. The relationship may depend on a host of factors, including the individuals involved at any given time and how successfully the subcontract is proceeding. At the extreme end, under previous programmes, there have been complaints of malpractice from primes towards subcontractors, such as late payment or subcontractors being frozen out (WPC, 2010;2009). Primes also, in some cases, removed poorly performing subcontractors, either by mutual consent or more rarely by terminating contracts (Foster et al., 2014). Prior to this point, primes might apply a period of performance management activity, including potentially a reduction in referrals.

Primes ability to control referrals appears to be one of the most important powers available to primes, and a notable point of concern amongst subcontractors (Foster et al., 2014). Subcontractors run the risk of receiving low numbers of referrals if primes keep those users 'in-house', or only users least likely to find work and trigger an outcome payment (Hudsen et al., 2010; WPC, 2010). Both would translate into lower outcome payments under the payment by results model. A decline in the overall number of referrals for the Work Programme, reflecting an improving labour market, may have exacerbated these issues.

Data on Talent Match partnerships do not reveal whether any delivery partners were subject to performance management activity, including having their contract removed or referrals reduced. However, given that many were paid using a fixed grant, and many were responsible for the outreach and recruitment of young people themselves, the issue of referrals was unlikely to be as much of a live area of concern as in the Work Programme.

${ }^{6} 2018$ figures are non-comparable, as an extra category 'by activity/services delivered' was added 
Overall, relations between primes and subcontractors varied, sometimes depending on the performance of the subcontract. By 2014, 40 per cent of subcontractors felt their monitoring and management by their prime was effective, with 22 per cent feeling it was ineffective. 70 per cent felt that their relationship with their prime was positive overall, with the remainder neutral or negative. Some criticisms included suggestions that their performance management was excessive and onerous. More serious disputes over outcome payments were also alluded to, though it is noted that no formal complaints were recorded as part of the 'Merlin Standard' arbitration process.

Relationships between Talent Match partnership leads and delivery partners also appears to have been predominantly positive. Interviews with delivery partners acknowledged the key role that the lead partner played and were generally supportive, whilst accepting that working in partnership inevitably brings challenges relating to communication and cross-organisational management. The responses to the partnership delivery survey in 2018 were also generally positive, even more so than in earlier waves. The results all indicate disagreement or dissatisfaction in only a small minority of cases:

- 77 per cent of delivery partners agreed that they had support from their lead partnership (67 per cent in 2015, 65 per cent in 2014), with six per cent disagreeing (eight per cent in 2015, six per cent in 2014) and 17 per cent responding that they were neutral or did not know (22 per cent in 2015, 25 per cent in 2014).

- 89 per cent of respondents agreed there were good delivery arrangements within their partnership (up from 73 per cent in 2015, 70 per cent in 2014), with only five per cent disagreeing (nine per cent in 2015, 12 per cent in 2014). Six per cent were neutral or did not know (17 per cent in 2015, 15 per cent in 2014). 


\section{Service design}

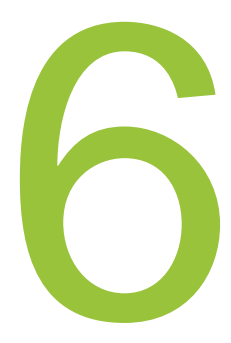

This chapter explores the actual delivery and service design on the Work Programme and Talent Match. It starts by considering the level of flexibility that providers on both programmes were afforded to design their own services. The recruitment of participants onto both programmes is then explored, though clearly this has a different meaning on the compulsory Work Programme compared to the voluntary Talent Match programme. The characteristics of those who did go on to participate in the programme are then considered, including the barriers to work and any disadvantages they reported. The actual services of fered to these individuals are then explored, including any in-work support and employer engagement. The extent to which providers were able to utilise their flexibility on both programmes to innovate or develop their services as the programme progressed is also considered. Finally, there is a discussion of the extent to which resources may have been targeted at those closer to, or further from, the labour market.

\subsection{Central specification levels}

The Work Programme applied a 'black box' strategy towards providers' services. Under this model, primes were in theory granted flexibility over their delivery model and judged instead purely on their results. Unlike previous programmes, no mandatory, minimum service standards were specified by the DWP. This flexibility was meant to enable individualised services for a wide variety of benefit claimants, reduce monitoring costs, and to allow innovation (Foster et al., 2014; Struyven and Seurs, 2005). However, in their bids, primes were obliged to set out their own minimum service standards, which were then embedded into their contracts. Examples included participant engagement timescales, levels of contact, and ensuring all participants had an action plan and a CV.

Several sources argued that these specifications were vague and unenforceable (Finn, 2011; WPC, 2015). The official evaluation did find some evidence of primes failing to meet these commitments or stretching their interpretation. However, it also found evidence of primes being held to their commitments (Foster et al., 2014). The DWP did not allow major changes to Prime's minimum standards, and in general they appear to have been taken seriously as a contractual requirement, equal in status to the minimum performance targets. Some primes and subcontractors felt that these commitments had severely limited the 'black box' approach and their ability to innovate (Lane et al., 2013). They argued that in some circumstances the standards had proved inappropriate in practice, potentially leading to less relevant provision or demoralising participants (Foster et al., 2014). Others complained of the high level of bureaucracy created by reporting and monitoring on minimum provision.

Despite the centrality of the black box to the design of the Work Programme, however, it is notable that Talent Match arguably embodies its principles to an even greater degree. Although partnership leads outlined their proposed activities in their 
business cases to the Fund, there were no formal minimum delivery standards. This partly reflects the voluntary nature of the programme, which meant that the degree of participation was dependent upon the wishes of the young people involved. Talent Match also aimed to implement a test and learn approach, meaning the Fund was open to partnerships reworking their delivery models over the course of the programme.

At the subcontractor level, Work Programme subcontractors appear to have generally been afforded the same level of flexibility as primes. The clear exceptions were in cases where subcontractors were deemed to be underperforming. In the same way that some primes complained of creeping intervention by the DWP over the course of the programme, some subcontractors suggested that primes' willingness to intervene was gradually increasing (Foster et al., 2014). The evaluation claims that around 50 per cent of subcontractors reported they had flexibility in their services and 40 per cent that they had little or no flexibility, though this latter group may have included more 'non-end-to-end' provision, based around a particular service.

Prescription by the Talent Match partnership leads, similarly, does not appear to have been common practice. They appear to have largely allowed their delivery partners to operate autonomously. In the 2018 survey almost all delivery partners (98 per cent) indicated that they have at least some independence from the lead partner over how they chose to deliver their services (2018 question only). This included 29 per cent with total independence. Overall, therefore, both partnership leads and delivery partners appear to have had a large degree of autonomy and an ability to devise their own activities and interventions.

\subsection{Engaging participants}

The first stage in a participant's 'journey' on either programme is their official referral or attachment to a provider. As the Work Programme was compulsory for most participants, this process was clearly very different compared to Talent Match. Eligibility for the Work Programme depended on users receiving certain benefits, particularly 'Job Seekers Allowance' and 'Employment and Support Allowance'. 1824-year olds on Job Seekers Allowance were referred from the Job Centre Plus 9 months after their initial benefits claim if they remained unemployed, or after three months if NEET (not in employment, education or training) (DWP, 2017). ESA claimants were generally referred as soon as allocated into the 'Work Related Activity Group' by their 'Work Capability Assessment'. An initial appointment would generally be either face-to-face or by telephone (Foster et al., 2014).

Talent Match participants, in contrast, did not have to be in receipt of benefits. In fact, the initial focus of the programme was concerned with young people not on benefits and therefore 'hidden' from mainstream employment support. Along with the early focus on NEET 'hotspots', this was partly to ensure that Talent Match provision avoided replicating existing Work Programme provision. Participation was also originally limited to those unemployed for 12 months or more and not in any form of training (Big Lottery Fund, 2012). In practice, all these restrictions were interpreted flexibly and relaxed further as the programme progressed. Over the course of the programme, 49 per cent of Talent Match participants reported at baseline that they received Job Seekers Allowance and 16 per cent reported receiving Employment and Support Allowance. Potentially, entry requirements were relaxed partly due to the improving jobs market, which reduced the pool of potential participants as the programme progressed. As with the reduced focus on geographical targeting, some partnerships appear to have maintained tighter restrictions on participation than o thers. There remains a balance between flexibility and clarity, and interactions with the 
evaluation team suggested that there was some confusion amongst providers on what was, and was not, permitted.

In contrast to Work Programme providers, who had little ability to influence referral numbers, Talent Match partnerships were all engaged in varying degrees of outreach activity to recruit young people. Across all three waves of the delivery partner survey (2014, 2015 and 2018), providers were asked what proportion of their participants came from various referral sources. The mean responses are shown in Table 6.1. The most common route, on average accounting for over a third of referrals at all waves, was 'referrals from other organisations'. This was closely followed by 'outreach by your organisation', again accounting on average for around a third of all referrals. Other common routes were via 'existing / previous clients' and 'peer contacts'.

Table 6.1: Sources of referrals - average percentage estimated by providers

\begin{tabular}{llll}
\hline & 2014 & 2015 & 2018 \\
\hline Referrals from other organisations (\%) & 39 & 42 & 36 \\
Outreach by your organisation (\%) & 32 & 32 & 33 \\
Existing/previous clients (\%) & 13 & 16 & 15 \\
Peer contacts (\%) & 12 & 9 & 12 \\
Drop-in open access facility (\%) & 7 & 9 & 9 \\
Events (\%) & 7 & 6 & 7 \\
Marketing and advertising (\%) & 6 & 9 & 9 \\
Other (\%) & 7 & 3 & 14 \\
\hline
\end{tabular}

Base 83 (2014), 94 (2015), 104 (2018)

Partnerships were also asked about their main referral route using an open text question. The results largely reflected those in Table 6.1, specifying organisations or peer-to-peer approaches. Notably, the Job Centre or Work Programme provided one common referral route. It is not clear whether these organisations ever mandated young people to participate in Talent Match or if their participation counted towards their 'mandatory job search activity', which might have impinged upon the voluntary nature of Talent Match.

Overall, delivery partners appear to have been satisfied with their recruitment strategies. Delivery partners were asked if they agreed that they had the ability to reach their Talent Match target groups. 85 per cent agreed or strongly agreed in the 2014 survey, rising slightly to 86 per cent in 2015 and 92 per cent in 2018. Because Talent Match partnerships had more control over who they recruited onto the programme, there was also the potential to target sub-groups of young people. Just less than half of partnerships (46 per cent) were doing so in 2015 (question not asked in 2014), but this seems to have dropped notably by 2018 ( 28 per cent).

\subsection{Participant characteristics}

The differences in entry onto both programmes are likely to have resulted in some differences in the aggregated characteristics of the programme users. Comparisons between the participants of Talent Match and similarly aged participants on the Work Programme are challenging, however, due to a lack of comparable data. The official figures for 18-24-year olds attached to the Work Programme provide demographic data only on gender, disability and ethnicity. A wider variety of results are available via the Work Programme participant survey (Meager et al., 2014), but these refer to all 
participants, not just those aged 18-24. Nevertheless, it is possible to derive the following comparisons:

- Around two thirds (62 per cent) of young people participating in Talent Match are male, which is comparable to the Work Programme (66 per cent)

- 22 per cent of Talent Match participants identify as part of an ethnic-minority (all categories except for 'White British' and 'White Irish'). The comparable figure for the 18-24-year olds on the Work Programme is slightly lower at 15 per cent.

- 23 per cent of Talent Match participants have a physical or mental health condition expected to last over 12 months. The official figures for 18-24 year olds on the Work Programme only specifies that 20 per cent have a disability (the definition of which is unclear). The figure for the participant survey (Meager et al., 2014), however, uses a similar definition to Talent Match. Albeit for all ages, this provides a comparable figure of 22 per cent.

- Using the Work Programme participant survey (for users of ages of participants), 59 per cent of participants lived in the most deprived quartile of areas nationally. This compares to 66 per cent of Talent Match participants.

These basic characteristics suggest that participants on the Work Programme and Talent Match are not too dissimilar in demographic terms. Both appear to have worked with a broad cross-section of young unemployed people. Although both worked with disabled participants, neither was a specific disability focussed scheme or aimed to work with the most severely disabled individuals. A slightly higher proportion of Talent Match participants were from ethnic minorities, particularly in the London partnership.

\subsection{Barriers to work}

Demographic measures on their own, however, are unlikely to tell us how far from the labour market young people are when starting on a programme, or their personal barriers to finding work. The Talent Match evaluation recorded a relatively high amount of information on these barriers, such as homelessness, mental health or addiction, whereas the Work Programme did not officially measure these in any systematic way (WPC, 2015). Again, however, it is possible to draw on the Work Programme evaluation's surveys of providers and participants, but with the major caveat that this contains participants of all ages. Participants were asked to identify the main difficulties they faced in finding work. For both the Talent Match and Work Programme data, participants were free to identify all the barriers that applied.

- Notably, the results for Talent Match suggest higher frequencies of barriers and negative experiences than those for the Work Programme, as reported by participants. While this may reflect genuinely higher levels of need amongst Talent Match participants, it should be born in mind that there could also be differences in how the questions were asked in the Work Programme survey that are not immediately apparent from the evaluation report.

- The most common barrier identified by Talent Match participants was a 'lack of prior work experience' (52 per cent). A much smaller percentage of Work Programme participants identified this as an issue (15 per cent), though this may be partly related to their higher average age.

- Another common barrier for Talent Match participants was a 'lack of job opportunities locally' (49 per cent), compared to 21 per cent of Work Programme participants who reported 'lack of jobs in local area' as a key barrier. Potentially, this difference could relate to the geographically targeted focus of Talent Match compared to the more universal Work Programme. 
- One of the starkest differences was that only two per cent of Work Programme survey participants identified 'lack of confidence' as an issue, compared to 47 per cent of Talent Match participants. This matches markedly low levels of wellbeing identified amongst Talent Match participants (Wilson et al., 2019).

- A similarly big gap was found for those reporting a 'lack of interview skills' (two per cent for the Work Programme and 37 per cent for Talent Match.

- On the other hand, similar levels of Work Programme respondents reported 'Family or caring commitments (childcare)' (five per cent) to 'other responsibilities (e.g. caring)' for Talent Match participants (also five per cent).

- III-health and disability was rated as an issue for 13 per cent of Work Programme respondents and for 24 per cent of Talent Match respondents. This is somewhat surprising, given the similar rates of disability overall identified above.

- Finally, 11 per cent of Work Programme respondents reported abarrier relating to 'not having right skills or qualifications for jobs interested in'. Talent Match participants reported 44 per cent for 'lack of job specific skills' and 49 per cent for 'lack of qualifications'.

Less comparable, but still worth noting, three per cent of Talent Match participants responded positively to 'I have experienced alcohol dependency' and seven per cent to 'I have experienced drug dependency'. Only half a per cent of Work Programme respondents identified 'drug or alcohol' problems as a barrier to employment. Similarly, 12 per cent of Talent Match respondents had a criminal record of some kind, but only two per cent of Work Programme participants identified 'criminal record' as a barrier. In both cases, these measures are slightly different, but they do help to highlight the significant adverse experiences reported by many Talent Match participants.

\subsection{Services offered}

As established above, providers on both programmes had a reasonable degree of autonomy to determine their own services and delivery model. However, Talent Match providers had a higher level of resources per participant and were less restricted by service standards set at the bidding stage. Talent Match was also voluntary sector led, and as Aiken (2007) outlines, voluntary sector organisations have a long history in approaches that develop human and social capital by investing in individual training and subsidised employment opportunities. Given all these factors, we might speculate that compared to the Work Programme, Talent Match would feature more intensive and developmental interventions rather than the 'Work First' interventions outlined in Chapter 3. Unfortunately, many of the categories and measures used in both the Work Programme and Talent Match evaluations to identify types of services do not overlap. This clearly makes comparison difficult. Furthermore, for both evaluations, different sets of categories were used when asking providers what services they delivered, compared to asking participants what services they received.

In the few areas where comparison is possible, the differences involved are modest. For example, 63 per cent of Talent Match delivery partners in 2014 reported offering help with 'job search' (66 per cent in 2015, 80 per cent in 2018) similar to 67 per cent of end-to-end Work Programme providers. 63 per cent of Talent Match providers in 2014 also offered support with 'soft skills (or life skills e.g. confidence building)' (80 per cent in 2015, 81 per cent in 2018), while 68 per cent of end-to-end Work Programme providers offered 'support in building personal effectiveness / confidence building'. Some differences were apparent, however. 'Temporary work placements' were widely offered on the Work Programme (63 per cent of end-to-end providers), but 'work experience / placements' were offered by even more providers on Talent Match (81 per cent in 2014 and 2015, 84 per cent in 2018). Work Programme end-to-end 
providers were much more likely to offer 'Advice / support on self-employment or business start-up' (67 per cent) compared to 11 per cent of Talent Match delivery partners in 2014 offering 'pre-enterprise advice and support' (though this jumped to 48 per cent in 2015 and 41 per cent in 2018).

At the individual level, 40 per cent of Talent Match participants reported receiving training for 'basic skills (reading/numbers)', higher than the 14 per cent who reported receiving 'support or training in maths, reading, writing or English language' in the 2012 Work Programme telephone survey (18 per cent in 2014). 47 per cent of Talent Match participants reported receiving some form of 'financial support'. In contrast, 36 per cent of Work Programme participants reported receiving 'financial support to help cover the costs associated with looking for work (e.g. travel expenses or childcare costs)' in the 2012 survey (42 per cent in 2014).

The higher number of Talent Match providers offering work experience placements is matched at the individual level. 43 per cent of Talent Match participants had undertaken some form of Work Experience during their time on the programme, while 33 per cent had undertaken some form of volunteering. In contrast only 15 per cent of respondents to the 2012 Work Programme survey reported having undertaken a 'a work experience placement or voluntary work' during their time on the programme (19 per cent in 2014). Talent Match participants were also more likely to have 'taken up additional training' since starting on the programme (48 per cent) compared to Work Programme participants who had 'received a place on a training course' (17 per cent in 2012, 27 per cent in 2014).

At a minimum, participants on both programmes also appear as though they were able to receive a range of 'work first' interventions relating to various types of advice and support. The most common Work Programme responses were 'help with writing a CV, job applications or interview skills' (64 per cent in 2012, 75 per cent in 2014), and 'drawing up an action plan' (49 per cent in 2012, 68 per cent in 2014). The most common Talent Match responses were 'one to one support' (98 per cent), 'information, advice and guidance about careers' (94 per cent) and 'advice on personal development' (87 per cent).

The picture is less clear on the extent to which Talent Match offered an additional tier of more intensive and expensive interventions. As outlined above, we know that Talent Match participants were more likely to undertake training, including basic skills support, work experience, and or volunteering. And while we don't have comparable Work Programme figures, we also know that 17 per cent of Talent Match participants received 'counselling', 73 per cent received support with 'practical barriers' and 27 per cent received 'peer mentoring'. Comparably intensive interventions explored in the Work Programme surveys, such as 'help with housing issues' (8 per cent in 2012, 7 per cent in 2014), were rarer.

Overall, the Work Programme evaluation suggests that the emphasis was largely restricted to Work First types of intervention, and that this intensified over the course of the programme as training-based interventions were scaled back (Foster et al., 2014). Talent Match also appears to have delivered work first style interventions as the mainstay of its provision but was also more likely to arrange a range of additional, more intensive interventions, at least to some degree.

\subsection{In work support}

The Work Programme appears to have offered a high degree of in-work support to participants compared to predecessor public employment services. This reflects, in part, the emphasis on sustained employment in the payment model. 85 per cent of end-to-end Work Programme providers offered in-work support to 90 per cent or over 
of their participants (Foster et al., 2014). In contrast, 65 per cent of Talent Match delivery partners provided in-work support ( 73 per cent in 2015, 81 per cent in 2018). Given that this is likely to include some specialist providers, it is likely that Talent Match was also able to offer in-work support to most participants who found work, at least towards the end of the programme. Not all individuals offered in-work support choose to receive this support, however. Of those who secured an employment outcome at some point on Talent Match, only 54 per cent received any in-work support. The comparable figure is not available for the Work Programme, but of the take-up rates reported by end-to-end survey respondents, the median level was 61-70 per cent. A more in-depth discussion of in-work support on Talent Match is provided by Green et al. (2017).

\subsection{Employer engagement}

One area where Talent Match activity appears to have been slightly less than the Work Programme was engagement with employers. 88 per cent of end-to-end Work Programme providers surveyed in 2013 reported contacting employers to 'identify vacancies' (83 per cent in 2014), and only six per cent reported no engagement with employers (11 per cent in 2014). The Talent Match delivery partner survey does not have completely comparable questions, but only 20 per cent reported conducting 'job brokerage' in 2014 (46 per cent in 2014, 51 per cent in 2018) and 24 per cent reported engaging employers to act as 'employer mentors' (28 per cent in 2015, 33 per cent in 2018). This still indicates a reasonable degree of engagement, increasing over the programme. It is also possible that employers were more likely to engage with Work Programme providers who had considerably larger flows of potential applicants to offer in return.

\subsection{Service innovation}

The Work Programme evaluation found little evidence of innovation in service design and delivery amongst providers (Foster et al., 2014). A range of previous evaluations of employment services noted that providers tend to converge on a relatively similar model, involving a personal advisor and a personalised action plan (Hills et al., 2001; NAO, 2006). As established previously, the Work Programme largely offered afamiliar set of 'work first' interventions, such as help with CVs, job searching and interview training (WPC, 2015).

Rarer examples of innovation included a personal budgets pilot, new approaches to in-work support, and co-location within the local Job Centre Plus. Some providers also experimented with group provision, though this appears to have been primarily driven by a need for cost savings. This lack of innovation may have been partly because of a lack of resources. Considine et al. (2018) suggest that innovation and high-quality services are both expensive options. Bredgard and Larsen (2008) relatedly suggest that providers are instead more concerned with survival within the market than taking risks with new methods. The added risk of payment by results may therefore have inhibited further risk taking within the Work Programme (WPC, 2015).

Talent Match, in contrast, was comparatively well resourced and a diversity of approaches were encouraged by the Fund at the business development stage. As established, most providers delivered a foundation of reasonably similar 'work first' interventions, as well as some more intensive interventions. More pronounced differences between partnerships were also observed, however, with some choosing to partially specialise or target their resources on certain issues. For example, the Liverpool partnership focussed increasingly on mental health barriers in response to the needs their young people were presenting with upon entering onto the programme. 
Similarly, the Humber partnership pioneered a specialist in-work support service to support employers taking on young people with a learning or hidden disability.

It is also worth noting that the involvement of young people, as discussed in Chapter 3 , constitutes one of the most innovative aspects of Talent Match provision and governance. 60 per cent of providers in 2014 reported that young people were involved in designing service delivery (64 per cent in 2015). 47 per cent reported young people were involved in service delivery itself ( 50 per cent in 2015 ) and 44 per cent that young people were involved in 'marketing and advertising' (50 per cent in 2015). The most common form of participation was in 'engaging other young people / outreach', reported by 77 per cent of providers (76 per cent in 2015). A much more in-depth discussion of the involvement of young people is available in a previous publication from the Talent Match evaluation (Bashir et al., 2018).

Table 6.2 Forms of youth involvement in delivery

\begin{tabular}{lcc}
\hline & $\mathbf{2 0 1 4}$ & $\mathbf{2 0 1 5}$ \\
\hline Engaging other young people/Outreach & $77 \%$ & $76 \%$ \\
Designing methods of service delivery & $60 \%$ & $64 \%$ \\
Delivering services & $47 \%$ & $50 \%$ \\
Marketing and advertising & $44 \%$ & $50 \%$ \\
Media and dissemination & $27 \%$ & $41 \%$ \\
Management of service delivery & $22 \%$ & $23 \%$ \\
Other & $16 \%$ & $10 \%$ \\
\hline
\end{tabular}

Base 86 (2014), 105 (2015)

\subsection{Test and learn}

As already discussed, some Work Programme providers felt that ability to adapt their services as the programme progressed was limited by their commitment to minimum service standards in their contracts. Arguably, they also lacked the resources to substantially change their operating model beyond achieving cost savings (Foster et al., 2014). The Work Programme evaluation noted that the emphasis on Work First interventions for most clients increased as attachment fees were phased out, and referrals (and therefore outcome payments) proved lower than expected (Lane et al. 2013). The exception appears to be that some changes were observed in the degree of provision on offer for disabled participants' in receipt of Employment and Support Allowance. Having missed initial targets for this payment group, pressure on providers to deliver suitable services to this specific group increased. This led to a moderate increase in specialist provision and, in some cases, even new specialist subcontractors (Foster et al., 2014). It is notable, therefore, the extent to which any redesign of services appeared to depend largely on the payment model or contractual pressure from the DWP.

In contrast, the Fund explicitly supported a 'test and learn' approach. 42 per cent of delivery partners responding to the 2018 survey had changed the ways in which they delivered activities or services. This admittedly leaves a majority suggesting they made no significant changes, though what counts as significant is obviously partially a matter of interpretation. It is also worth noting that for almost every type of service queried in the delivery partner survey, a greater proportion of providers were offering the service 
by 2018 compared to 2014 . This suggests that overall partnerships were gradually increasing the range of their provision over the course of the programme.

Talent Match providers that did report changes were asked to provide further information as part of an open text question. Unsurprisingly, these responses exhibited a great deal of diversity, with many changes relating to the internal structure and operation of the partnerships rather than their services. This included partnerships adding new strategic partners or shifting their approach to geographical targeting. There were also a range of responses, however, indicating the addition of new activities or services. Examples included group work and new workshops, wellbeing and mental health interventions, monetary awards, and a range of different forms of youth involvement.

In contrast to the conclusions from the Work Programme evaluation, therefore, there does appear to have been a reasonable degree of change within Talent Match, implemented over the course of the programme. 92 per cent reported that the changes they had made either improved their delivery a lot ( 71 per cent) or a little ( 21 per cent). Only two per cent identified no difference, and a further two per cent that the changes had made delivery worse. Although it is positive that the providers overwhelmingly believe the changes improved services, too high a success rate could suggest that partnerships remained relatively risk averse in their decision making. It is also possible that providers were more willing to share their successes than their failures via the evaluation survey. Despite the messaging from the Fund, it is therefore possible there remained a tension between meeting engagement and employment targets and innovation or development.

\subsection{Creaming and parking}

Programmes such as the Work Programme and Talent Match, which allow the range of interventions to be personalised for each individual, require some form of service allocation process. The process by which these decisions are made within employment services has been consistently controversial (Carter and Whitworth, 2015; WPC, 2010). The primary fear is that in pursuit of job outcomes, and where applicable outcome payments, providers will focus their efforts only on those closest to the labour market. Where there is discretion over who to take onto the programme, this may take the form of 'creaming': only recruiting only those most likely to find employment. Where there is less discretion over recruitment, as for the Work Programme, 'parking' is more likely. This means providing those individuals less likely to find a job either minimal or no provision.

Commentators identified arange of factors which were likely to push Work Programme providers towards parking participants. These include the flexibility providers had to design their own service provision, resource pressures, contractual pressures, the wide range of users on the same programme, the high focus on job outcomes, and very low claimant leverage, choice or power (Carter and Whitworth, 2015; Rees et al., 2014). Previous evaluations have found that an intensification of the payment regime or performance targets almost always drives behaviour towards creaming and parking, as well as more generalist provision (Stafford et al., 2007; Hudsen et al., 2010).

The Work Programme payment groups were designed in part to mitigate these risks and incentivise providers to work with the harder to help benefit groups. By placing Employment Support Allowance claimants, in particular, providers could unlock much higher outcome payments. In practice, however, payment groups based on benefit type are a very crude measure of distance from the labour market (Carter and Whitworth, 2015; WPC, 2015). As a result, variation within groups can far outstrip variation between groups. Payment groups were also seen as complex, offering insufficient incentive to work with ESA claimants (Foster et al., 2014). In practice, only 
seven per cent of respondents to the 2014 provider survey suggested that they determined levels of provision based on the payment fee (Meager et al., 2014).

As a result, parking participants does appear to have been commonplace within the Work Programme (Rees et al. 2014). 43 per cent of respondents to the 2014 provider survey reported that they prioritised those with the best chance of moving into work. 40 per cent claimed that they prioritised those with the greatest support needs. 15 per cent based their allocation decisions on an overall calculation of whether the costs were covered by the likely payment. Qualitative interviews with providers further reinforced the idea that proximity to the labour market was the driving force for targeting resources, followed by an assessment of individual need (Lane et al. 2013; Foster et al., 2014).

One further factor did appear capable of shifting targeting behaviour. Prime's underperformance against their minimum performance levels led to increasing pressure over time from the DWP to improve results for ESA benefitrecipients, in some cases leading to performance management measures (Foster et al., 2014). In some cases, this led to an increase in specialist provision, in contrast to the general intensification of work first activities. This provision appears to have been funded partly due to increased referrals into this group as the programme progressed, but also due to cross-subsidisation from the outcome payments of JSA claimants.

The design of Talent Match, in contrast, does not appear to push providers towards creaming and parking to the same extent as the Work Programme. Resources per participant were higher, there was less contractual pressure to achieve results and no payment by results. Most providers were also voluntary organisations, whose social mission may, at least in theory, counter act any pressure to achieve results at the expense of equitable provision. On the other hand, unlike Work Programme providers, Talent Match providers had the theoretical option of creaming by prioritising individuals closer to the labour market in their recruitment. Previous evaluations have also suggested that even targets alone, without payment by results, are capable of radically shifting provider behaviour as they seek to appear successful (Hills et al. 2001).

In practice, recruitment by Talent Match providers does not appear to have been particularly selective. The 2018 delivery partner survey asked providers to specify the two most important factors determining who they worked with (Table 6.3). 48 per cent had their referrals process specified in their Talent Match contract, presumably with the partnership lead. 38 per cent were referred young people from other organisations. 35 per cent indicated a process of matching their skills to the young persons need, and 26 per cent the 'characteristics of the young person'. 25 per cent suggested they had no selection criteria, accepting any young person who approached the organisation.

As outlined earlier, there is also ample evidence that substantial proportions of Talent Match participants had considerable barriers to employment or previous negative life experiences. 16 per cent of participants, for example, had previously experienced homelessness. 12 per cent had a criminal record, and nine per cent had been in local authority care. Seven per cent had experienced drug addiction. Although it is difficult to define the 'correct' level of need for programme participants, these barriers seem unlikely to be as prevalent in the face of widespread creaming. More detail on 'targeting' within Talent Match is available in an existing evaluation report (Crisp et al. 2018). 
Table 6.3: Factors determining which young people partnerships supported

\begin{tabular}{lr}
\hline Factors determining which young people to support & 2018 \\
\hline Specified requirement in your Talent Match contract & $48 \%$ \\
Referrals & $38 \%$ \\
Matching your skills to the needs of the young person & $35 \%$ \\
Characteristics of the young person & $26 \%$ \\
Taking on any young person who approaches the organisation & $25 \%$ \\
Advice of a key worker & $10 \%$ \\
Other & $6 \%$ \\
\hline
\end{tabular}

Base 126

Determining the most appropriate level of support is inevitably going to involve a degree of subjectivity. Arguably, by targeting those closest to the labour market and most likely to trigger secure job outcomes, Work Programme providers were operating entirely within the aims of their programme: namely to reduce unemployment by as much as possible. Focussing too many resources on the hardest to help could be at the expense of a larger number of those closer to the labour market, who might derive great benefit from support over the final threshold into work. On neither Talent Match nor the Work Programme was there an explicit requirement to target resources towards those most in need, beyond the minimum set length of unemployment. If Talent Match partnerships did so, therefore, it is likely to have been a mission led decision rather than due to direct pressure from the Fund.

There is no straightforward measure of the intensity of support offered on Talent Match, which makes it difficult to determine whether any parking may have occurred following engagement. The best available measure is the number of different types of support that participants received, though clearly this does not account for the intensity of those types of support, and may miss out numerous types not provided as options. Nevertheless, there does appear to be a small relationship between the 'distance to the labour market' measure (see Wilson et al. 2019 for more details) and the number of types of support offered. Those in the group 'furthest from the labour market' received an average of 6.1 interventions, while those in the 'nearest to the labour market' group received an average of 5.5.

Most partnerships (78 per cent) also suggested that they were able to be flexible, at least up to a certain amount, in how much support they offered each individual young person (Table 6.4). This included 39 per cent who were able to be completely flexible. A further 18 per cent suggested that they offered 'defined levels of support depending on the needs of the young person'. Only four per cent suggested that all young people received the same support, perhaps reflecting specialist 'non-end-to-end' provision. 
Table 6.4: Determinants of how much support a young person receives

Determinants

Count

We are able to be completely flexible

$39 \%$

We tailor support to the needs of the young person up to a certain amount

$39 \%$

We offer defined levels of support depending on the needs of the young

$18 \%$ person

All young people receive the same support

$4 \%$

Base 126 


\section{Conclusions}

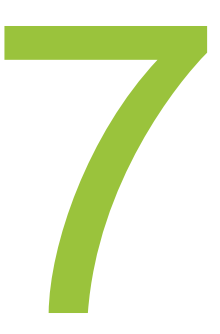

As this report has made clear, the Work Programme and Talent Match provide examples of two very different types of employment programme, but also notable similarities which aid their comparison.

The differences between the two programmes are perhaps the more obvious. Clearly, the two projects differed significantly in terms of their size and scope. The Work Programme was largely compulsory, while Talent Match was voluntary. Payment by results was much more predominant in the Work Programme. Talent Match was geographically targeted, the Work Programme operated nationwide. Relationships were also more hierarchical in the Work Programme, with higher potential for performance management. Talent Match participants were able to invest a higher level of resources into delivery for each participant. As a result of several these differences, incentives to cream or park appear to have been lower in Talent Match.

Whereas the work programme embodies the principles of the market and public sector contracting, notably payment by results, Talent Match arguably adopts a more network, partnership-based approach (Osborne 2006). From the bidding stage through to delivery, Talent Match utilised partnership as a core part of its ethos. This is borne out in several aspects of this report. The bidding process and contract management from the Fund was comparatively discursive and based on ongoing grant management procedures. Youth involvement also runs through many of the comparisons, acting as a key example of innovation reflecting a differing underlying ethos.

Perhaps less obvious, are the similarities between the two programmes. Both are 'supply side' labour market, targeted individual capabilities and assets, with much more limited interventions geared towards creating labour market opportunities via activities such as job subsidisation. Neither was a dedicated disability programme. Both offered a core of work-first interventions, though Talent Match also offered a range of more intensive interventions and the opportunity for youth involvement in partnerships. Both were divided into geographical regions, covered by direct contractors. Whilst implemented in different ways, therefore, both are examples of the 'prime' model of delivery, as opposed to more dispersed contracting models. Both exhibited relatively high levels of flexibility for these direct contractors, which was generally passed on to subcontractors and delivery partners. And both targeted employment outcomes as a central performance measure to set their core targets.

The differences between the two, therefore, are not always as clear cut as might be first assumed. Partnership working was found by the official evaluation of the Work Programme across several supply chains (Foster etal., 2014). While Talent Match, an overwhelmingly voluntary programme, partnerships by necessity received referrals in some cases from the Job Centre Plus. It is not, therefore, necessarily helpful to caricature either programme as the embodiment of either grant based, voluntary sector provision or of public sector outsourcing to monolithic private sector contractors. The reality is unsurprisingly more nuanced. 
By exploring in-depth, therefore, where the programmes contrasted in their design and operation, it is intended that they are both understand more clearly than in isolation. Although outcomes and value for money are outside the scope of this report, it is clearly necessary to understand the different context and design features of both programmes in order to judge their performance on their own terms. It is also possible to determine whether each has succeeded in implementing a programme in line with its own underlying ethos and principles.

It is particularly hoped that the comparison helps to highlight the many various design decisions which go into the implementation of a major employment programme. Various decisions taken in the design of Talent Match which may seem natural or lie implicit, are made explicit by having a tangible counter example and vice versa. This report therefore highlights that whilst in some ways Talent Match mirrors existing provision, in others it was a genuinely innovative and distinctive form of provision for young unemployed people.

\section{Lessons for policy}

Programme design is vitally important to the eventual character of a programme, including the behaviour of providers, the individuals who it helps and the services it delivers. If certain programme characteristics are desired, such as innovation over the course of delivery, targeting the hardest to help, or balancing job outcomes against 'softer' outcomes, then these need to be explicitly reflected in the programme design.

While Talent Match and the Work Programme were very different programmes, both lay on several spectra, including between human capital and work first approaches, partnership and performance management, and voluntary sector and private sector provision. In most cases, neither programme lies at the extreme point, and it is important not to caricature either as the perfect embodiment of a particular model or approach.

Talent Match could, if desired, have been differentiated even further from the Work Programme, whether by setting outcomes for intermediate outcomes, using a larger number of smaller contracts, or setting targets for engaging the very hardest to help. Talent Match might even have dispensed with an employment target, trusting providers to adopt an entirely holistic approach. These would not necessarily have led to a 'better' programme, but it is important to highlight that these are important design decisions for this and any future employment programmes.

Finally, it should be borne in mind that many of these design features have cost implications. Talent Match partnerships were able to spend a much higher average amount per participant than the Work Programme and it is this investment, above all else, which allowed innovation in its delivery and design. 


\section{References}

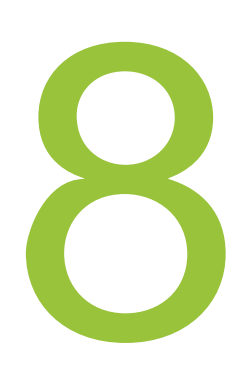

AVECO (2015) Youth Unemployment: The crisis we cannot afford. London: ACEVO.

Bashir, N., Pearson, S., Sanderson, E. and Wells, P. (2018) Talent Match Evaluation: Involving Young People. Birmingham: National Lottery Community Fund.

Big Lottery Fund, (2012) Talent Match Programme Guidance. Birmingham: The National Lottery Community Fund.

Bivand, P. (2011) Can the Work Programme succeed? Working Brief, February. London: Centre for Social and Economic Inclusion.

Bivand, P. and Melville, D. (2016) Work Programme Statistics Learning and Work Institute Analysis, March. Leicester: Learning and Work Institute

Bennett L., Bivand P., Ray K., Vaid L. and Wilson T. (2018) MyGo Evaluation: Final report, September. Leicester: Learning and Work Institute.

Bredgaard, T. and Larsen, F. (2008) Quasi-Markets in Employment Policy: Do They Deliver on Promises? Social Policy \& Society, 7(3), pp.341-352.

Carter, E. and Whitworth, A. (2015) 'Creaming and Parking in Quasi-Marketised Welfare-toWork Schemes: Designed out Of or Designed In to the UK Work Programme? Journal of Social Policy, 44 (2), pp.277-296.

Centre for Regional Economic and Social Research (CRESR) (2019) Talent Match Technical Report. Sheffield: CRESR.

Conlan, G., Patrignani, P. and Mantovani, I. (2014) The Death of the Saturday Job: The Decline in Learning and Earning Amongst Young People in the UK. UKCES.

Considine, M., O'Sullivan, S. and Nguyen, P. (2018) The Policymaker's Dilemma: The Risks and Benefits of a 'Black Box' Approach to Commissioning Active Labour Market Programmes. Social Policy and Administration, 52 (1), pp.229-251.

Damm, C., Green, A., Pearson, S., Sanderson, E. and Wells, P. (2018) Talent Match Evaluation: Youth Employment Partnerships, October. Birmingham: National Lottery Community Fund.

Department of Work and Pensions (DWP) (2017) Chapter 2, Work Programme Provider Guidance. London: DWP.

Ecorys (2017) Youth Employment Initiative Process Evaluation: Assessment of Strategic Fit, Design and Implementation, DWP Research Report 945, October. London: DWP. 
Finn, D. (2011) The design of the Work Programme in international context, Report for the National Audit Office. London: National Audit Office.

Foster, S., Metcalf, H., Purvis, A., Lanceley, L., Foster, R., Lane, P., Tufekci, L., Rolfe, H., Newton, B., Bertram, C. and Garlick, M. (2014) Work Programme evaluation: Operation of the commissioning model, finance and programme delivery, Research Report No 893, December. London: DWP.

Gadsby, B. (2019) Establishing the Employment Gap, April, Research Briefing 1. London: Impetus - Private Equity Foundation.

Greenberg, D., Knight, G., Speckesser, S. and Hevenstone, D. (2011) Improving DWP assessment of the relative costs and benefits of employment programmes, Working Paper No 100. London: DWP.

Impetus-PEF (2017) Youth Jobs Index, August, London: Impetus - Private Equity Foundation.

Lane, P., Foster, R., Gardiner, L., Lanceley, L. and Purvis, A. (2013) Work Programme Evaluation Procurement, supply chains and implementation of the commissioning model, Research Report No 832. London:DWP.

McQuaid R. (2015) Multiple Scarring Effects of Youth Unemployment, Skills in Focus 11. Glasgow: Skills Development Scotland.

Meager, N., Newton, B., Sainsbury, R., Cordon, A., Irvine, A. (2014) Work Programme evaluation: the participant experience report, Research Report No 892. London: DWP.

Mulheirn, I. (2011) Will the Work Programme Work? Examining the future viability of the Work Programme. London: Social Market Foundation.

National Audit Office (NAO, 2012) The introduction of the Work Programme, HC 1701, Session 2010-2012, January. London: National Audit Office.

National Audit Office (NAO, 2014) The Work Programme, HC 266, Session 2014-15, July. London: National Audit Office.

National Council for Voluntary Organisations (NCVO) (2019) UK Civil Society Almanac 2019, [online] available at: https://data.ncvo.org.uk/

Newton, B., Meager, N., Bertram, C., Corden, A., George, A., Lalani, M., Metcalf, H., Rolfe, H., Sainsbury, R. and Weston, K. (2012) Work Programme evaluation: Findings from the first phase of qualitative research on programme delivery, Research Report No 821.

Office of National Statistics (ONS) (2019) Rural population and migration September 2019, [online] available

at: https://assets.publishing.service.gov.uk/government/uploads/system/uploads/attachment da ta/file/834226/Rural population and migration September 2019.pdf

Osborne, S.P. (2006) The New Public Governance? Public Management Review, 8 (3), pp.377-387.

Rees, J., Taylor, R. and Damm, C. (2013) Does sector matter? Understanding the experiences of providers in the Work Programme, Working Paper 92. Birmingham, Third Sector Research Centre.

Rees, J., Whitworth, A. and Carter, E. (2014) Support for All in the UK Work Programme? Differential Payments, Same Old Problem. Social Policy and Administration, 48 (2), pp. 221239. 
Riley, T., Bivand, P. and Wilson, T. (2014) Making the Work Programme work for ESA claimants, April. London: Centre for Economic and Social Inclusion.

Simmonds, D. (2011) Work Programme results: perform or bust, Working Brief 7, May. London: Centre for Social and Economic Inclusion.

Struyven, L. and Seurs, G. (2005) Design and redesign of a quasi-market for the reintegration of jobseekers: empirical evidence from Australia and the Netherlands. Journal of European Social Policy, 15 (3), pp.211-229.

UK Commission for Employment and Skills (UKCES) (2012) The youth employment challenge, July. Wath-upon-Dearne and London: UKCES.

Work and Pensions Select Committee (WPC) (2009) DWP's Commissioning Strategy and the Flexible New Deal, HC 59-I. London: The Stationery Office.

Work and Pensions Committee (WPC) (2010) Management and Administration of Contracted Employment Programmes. HC 101. London: The Stationery Office.

Work and Pensions Committee (WPC) (2011) Work Programme: providers and contracting arrangements. HC 718. London: The Stationery Office.

Work and Pensions Committee (WPC) (2013) Can the Work Programme work for all user groups? HC 162. London:The Stationery Office.

Work and Pensions Committee (WPC) (2017) Employment Opportunities for Young People, HC 586, London: The Stationery Office. 


\section{Annex 1: Summary table}

Programme design - direct contracts

\begin{tabular}{|c|c|c|}
\hline & The Work Programme & Talent Match \\
\hline Programme size & $\begin{array}{l}\text { Final payments to contractors } \\
\text { estimated at } 22.4 \text { billion (NAO, } \\
2014 \text { ) }\end{array}$ & $\begin{array}{l}£ 108 \text { million total available } \\
\text { funding }\end{array}$ \\
\hline Delivery period & June 2011 to April 2017 & January 2014 to January 2019 \\
\hline Geographical coverage & $\begin{array}{l}\text { All of England, Wales and } \\
\text { Scotland, divided into regional } \\
\text { contract package areas }\end{array}$ & $\begin{array}{l}21 \text { selected LEP areas with high } \\
\text { areas of youth unemployment }\end{array}$ \\
\hline Role of the voluntary sector & $\begin{array}{l}\text { Predominantly private sector } \\
\text { contractors }\end{array}$ & $\begin{array}{l}\text { Voluntary sector led } \\
\text { partnerships }\end{array}$ \\
\hline Funding model & $\begin{array}{l}\text { Primarily 'payment by results' } \\
\text { on the basis of job outcomes }\end{array}$ & Grant funding \\
\hline Job outcomes & $\begin{array}{l}\text { Varied according to 'payment } \\
\text { group', based largely on } \\
\text { benefit type. Counted } \\
\text { sustained job outcomes only }\end{array}$ & $\begin{array}{l}\text { Recorded both sustained and } \\
\text { non-sustained job outcomes, } \\
\text { usually requiring } 16 \text { plus hours } \\
\text { per week }\end{array}$ \\
\hline Outcome targets & $\begin{array}{l}\text { Contractual minimum } \\
\text { performance levels for three } \\
\text { payment groups }\end{array}$ & $\begin{array}{l}\text { Overall job outcome target for } \\
\text { each partnership }\end{array}$ \\
\hline Resource levels & $\begin{array}{l}\text { Extremely tight and dependent } \\
\text { upon outcomes }\end{array}$ & $\begin{array}{l}\text { Fixed and more generous per } \\
\text { participant than the Work } \\
\text { Programme, though varied } \\
\text { significantly between } \\
\text { partnerships }\end{array}$ \\
\hline
\end{tabular}




\begin{tabular}{|l|l|l|}
\hline The Work Programme & Talent Match \\
\hline Subcontracting approach & $\begin{array}{l}\text { Varied between heavy } \\
\text { performance management and } \\
\text { competition between } \\
\text { subcontractors, and more } \\
\text { partnership based models }\end{array}$ & $\begin{array}{l}\text { Generally partnership based } \\
\text { between the lead partner and } \\
\text { 'delivery partners' }\end{array}$ \\
\hline Role of the voluntary sector & $\begin{array}{l}40 \text { per cent voluntary sector } \\
\text { subcontractors }\end{array}$ & $\begin{array}{l}74 \text { per cent voluntary sector } \\
\text { subcontractors }\end{array}$ \\
\hline Payment model & $\begin{array}{l}\text { Predominantly payment by } \\
\text { results for 'end-to-end' } \\
\text { subcontractors }\end{array}$ & $\begin{array}{l}\text { Predominantly fixed payments, } \\
\text { or payments by caseload or } \\
\text { activity }\end{array}$ \\
\hline
\end{tabular}

\section{Service design}

\begin{tabular}{|c|c|c|}
\hline & The Work Programme & Talent Match \\
\hline $\begin{array}{l}\text { Flexibility over service } \\
\text { design }\end{array}$ & $\begin{array}{l}\text { High flexibility as part of the } \\
\text { black box approach, but } \\
\text { subject to pledges made at the } \\
\text { contracting stage }\end{array}$ & $\begin{array}{l}\text { Very high flexibility as part of a } \\
\text { test and learn approach }\end{array}$ \\
\hline Participant eligibility & Based on time on benefit & $\begin{array}{l}\text { Initial restrictions relaxed as } \\
\text { the programme progressed }\end{array}$ \\
\hline Participant characteristics & $\begin{array}{l}\text { Predominantly male, white and } \\
\text { non-disabled }\end{array}$ & $\begin{array}{l}\text { Similar demographics to the } \\
\text { Work Programme, with } \\
\text { evidence of severe barriers to } \\
\text { work for some participants }\end{array}$ \\
\hline Types of services & $\begin{array}{l}\text { Work first interventions, some } \\
\text { disability specialist services as } \\
\text { the programme progressed }\end{array}$ & $\begin{array}{l}\text { Baseline of work first } \\
\text { interventions, but also } \\
\text { examples of more intensive } \\
\text { interventions when needed }\end{array}$ \\
\hline Innovation and development & $\begin{array}{l}\text { Limited by resources and } \\
\text { contracted minimum service } \\
\text { standards }\end{array}$ & $\begin{array}{l}\text { Some examples of innovation, } \\
\text { particularly youth involvement }\end{array}$ \\
\hline Targeting & $\begin{array}{l}\text { Based primarily on cost-benefit } \\
\text { calculations and likelihood to } \\
\text { trigger outcome payments }\end{array}$ & $\begin{array}{l}\text { Either contractually fixed, or } \\
\text { more flexible to individual need }\end{array}$ \\
\hline
\end{tabular}




\section{Sheffield Hallam University}

\section{Talent Match Evaluation: Comparative Report}

DAMM, Christopher <http://orcid.org/0000-0002-7355-3496>, GREEN, Anna and WELLS, Peter <http://orcid.org/0000-0002-5200-4279>

Available from the Sheffield Hallam University Research Archive (SHURA) at:

http://shura.shu.ac.uk/26572/

\section{Copyright and re-use policy}

Please visit http://shura.shu.ac.uk/26572/ and http://shura.shu.ac.uk/information.html for further details about copyright and re-use permissions. 